\title{
Wall-to-horizontal diaphragm connections in historical buildings: a state-of-the-art review ${ }^{\star}$
}

\author{
Fabio Solarino, ${ }^{\mathrm{a}, \mathrm{b}, *}$, Daniel V. Oliveira ${ }^{\mathrm{a}}$, Linda Giresini ${ }^{\mathrm{b}}$ \\ ${ }^{a}$ ISISE, Institute of Science and Innovation for Bio-Sustainability (IB-S), Department of \\ Civil Engineering, University of Minho, Guimarães, Portugal \\ ${ }^{b}$ Department of Energy, Systems, Territory and Constructions Engineering (DESTEC), \\ University of Pisa, Pisa, Italy
}

\begin{abstract}
Wall-to-horizontal diaphragm connections play a crucial role in the global stability of historical buildings under seismic actions. When these links are ineffective or absent, engineered measures should be considered to enhance the earthquake-resistant box-type behavior. Besides the great variety on the construction systems and materials, common damages were observed in recent seismic events showing the high vulnerability of local mechanisms promoted by the lack of structural integrity. Although the acknowledged importance of connections, this topic has been practically neglected over time among the research community and practitioners and only few of them focused on the influence of diaphragm-to-wall connections on the dynamic behavior of the building as a whole.

This paper presents a literature review of the traditional wall-to-floor or wall-to-roof connections in unreinforced masonry buildings and summarizes
\end{abstract}

\footnotetext{
${ }^{\star}$ This paper can be found at https://doi.org/10.1016/j.engstruct.2019.109559

${ }^{*}$ Corresponding author

Email address: solarino.fabio@gmail.com (Fabio Solarino)
} 
This paper can be found at https://doi.org/10.1016/j.engstruct.2019.109559

typical and innovative strengthening solutions, taking into account the indications provided by the few design codes addressing this topic. Experimental laboratory researches are investigated, including shaking table tests on global and local scale, and cyclic or monotonic tests to characterize anchoring systems. An overview of the typical vulnerability assessment approaches and modelling techniques is given, considering present standards that account for connections.

Keywords: unreinforced masonry buildings, wall-to-diaphragm

connections, out-of-plane collapse, strengthening techniques, design codes, state-of-the art

\section{Introduction}

Overturning of the perimeter out-of-plane (OOP) walls is considered the first-mode of failure and the last desirable in historical buildings [1, 2], cause of dramatic consequences, as shown in past seismic events in New Zealand 5 (1931 M7.8 Hawke's Bay earthquake), California (1933 M6.4 Long Beach earthquake), San Francisco (1989 M6.9 Loma Prieta earthquake), Australia (1989 M5.6 Newcastle earthquake), or in Nepal (1988 M6.9 East Nepal earthquake) [3], among others. Old masonry buildings are most susceptible to seismic motions not only because they were built following the "rules of art", but also because of lacking anti-seismic criteria and poor quality of the materials $[4]$.

Besides the in-plane (IP) stiffness of the floor, the connection quality between floors and vertical elements strongly influences the seismic response of existing URM buildings. Without proper connections, the walls behave like 


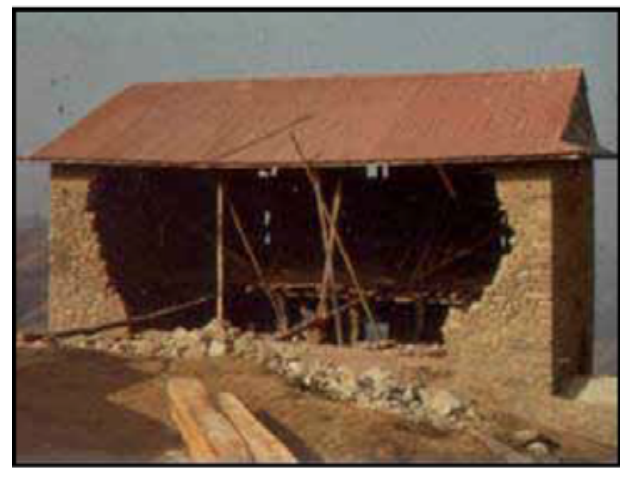

(a)

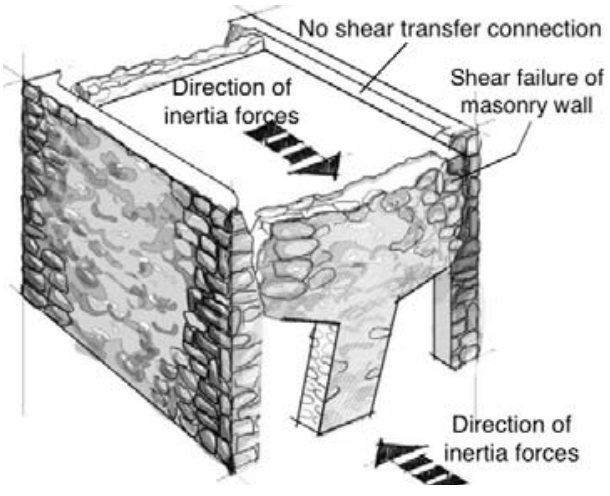

(b)

Figure 1: OOP failures of masonry walls due to the lack of wall-to-roof connections [6]: (a) collapse of a long wall in the 1988 East Nepal earthquake; (b) Inertia forces causing local failure mechanism

a tall unrestrained cantilever vibrating laterally, highly vulnerable to flexural OOP action [5, 6] (Figure 1(a)). Moreover, diaphragms play a key role in the transmission of the seismic actions through the shear connections to the lateral resisting walls (Figure 1(b)). Vertical seismic actions can also make the weak supports ineffective, causing the partial or total collapse of the structure. Effective solutions, together with the adoption of general seismic criteria, lower the vulnerability of the URM buildings ensuring the "boxbehavior" and activating global equilibrated mechanisms [7] (Figure 2(a)). On the other hand, inappropriate use of retrofit techniques can increase the seismic risk in existing constructions, as observed in failures during the 1997 Umbria-Marche earthquake (Figure 2(b)), where the increased seismic forces due to the new heavy roof caused the separation from the supporting walls. Researchers mainly aim at understanding the global seismic behavior of the building neglecting the influence of connections, and strengthening solutions 


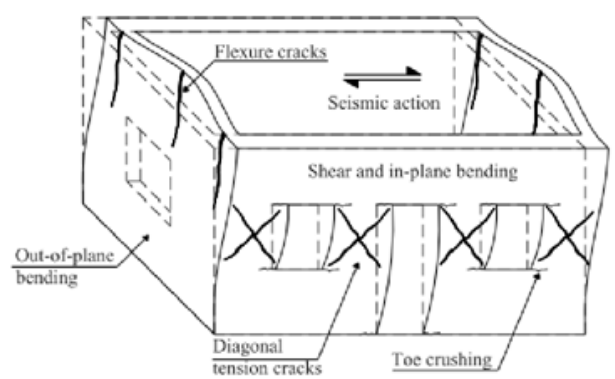

(a)

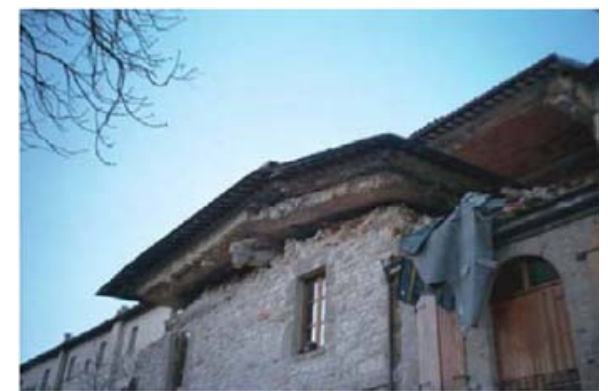

(b)

Figure 2: URM buildings seismically damaged: (a) global damage pattern embraced by Tomaževič [7]; (b) stiff diaphragm disconnected from walls [1]

are suggested for the solely primary structural elements [8, 9]. The importance to account for OOP loading of the walls and to guarantee proper connections is highlighted in design codes and guidelines, yet it is not clear how to account for these effects in analytical models. Eurocode 8, part 3 [10] gives general technical criteria specifically for masonry structures, for which inadequate connections between floors and walls or between roofs and walls should be improved and OOP horizontal thrusts against walls should be eliminated, but no assessment equations can be found to verify the quality of the current connections. The 2008 Italian code $[11,12]$ allows to perform kinematic analysis to assess local mechanisms of masonry structures constituted by macro-elements with a displacement-based approach. No suggestions can be found, however, on the value of stiffness of the connections between the OOP wall and the possible diaphragm. Circolare n. 26 [13], aligned with NTC08, highlights the importance of reducing lacks in connections proposing the use of tie rods, external bounding and ring beams. It is worthy to notice that this code only mentions some connection details for existing constructions 
This paper can be found at https://doi.org/10.1016/j.engstruct.2019.109559

45 (e.g. use of steel elements to anchor the timber beam to the masonry wall at floor level) without giving clear guidelines on how to account for them in the numerical models. Few details and recommendations can be found in the new NTC2018 [14] suggesting mechanical or injected anchor elements to increase the pull-out resistance. No analytical formulation is, however, suggested for the design and assessment of those connections.

This paper presents a state-of-the-art of traditional and innovative wallto-horizontal diaphragm connections solutions used in historical buildings to enhance the OOP strength of the URM walls. Section 2 reports the typical traditional connections, while Section 3 describes main strengthening techniques to reinforce wall-to-diaphragm connections in existing buildings. Experimental and numerical analyses are critically discussed in Sections 4 and 5, respectively, by considering the different modelling techniques and the role of current standards.

\section{Typical traditional connections}

${ }_{60}$ Investigating the actual type and characteristics of the connections between vertical and horizontal structures is a complex but fundamental task, influencing the accuracy of assessment models to evaluate the building vulnerability and to design the optimum strengthening solution. Moreover, details are not on sight and no drawings are available for ancient buildings. Post-earthquake surveys from the inside are often risky.

The great variability of connections mainly relies on the typology of structural elements (single, multi-leaf or cavity walls, columns, floors, roofs, arches and vaults), and on their materials (bricks, stone, timber, steel and reinforced 
This paper can be found at https://doi.org/10.1016/j.engstruct.2019.109559

concrete), but similarities can be found among construction systems in different countries worldwide. Either one- or two-way timber floors are typically used in masonry buildings, while timber truss is the most common type of roofing system. Traditional examples of connection details are summarized and discussed below.

A brief description about construction details typically found in older

75 the recessed support or, by using weak grout to fill an oversized rectangular cavity housing the support for the beams [26]. Historical treatises proposed 


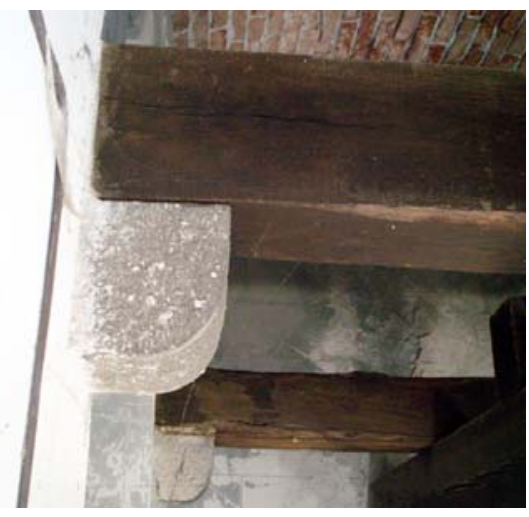

(a)

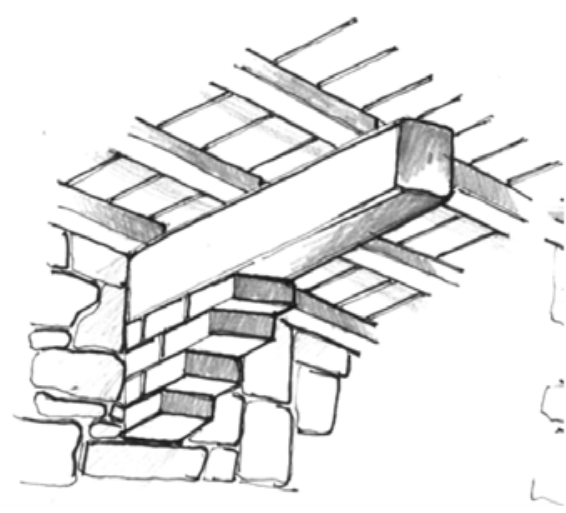

(b)

Figure 3: Timber beams on corbels: (a) Connection detail inside Castello d'Albertis, Genova, Italy [22]; (b) Example of bricks arranged as corbels to support timber beams [19]

solutions to avoid the decay of headpieces of the timber beams infixed in the masonry, such as, leaving a gap between the timber and the masonry allowing airing [20, 25], sometimes including a hole on the outer wall covered with a grid [27]. Formenti [28], Donghi [29] and Chevalley [30] suggested to form a box around the headpiece through air bricks or insert hardwood or stone brackets under the headpieces of the floor beams. Further solutions comprised timber wall-plate $(0.12-0.15 m$ thick $)$ fixed in $3 / 4$ or in the entire thickness of the wall linked to the joists through mortise and tenon joint type [31]. Another way to better distribute the load on the wall was the adoption of wrought timber beams as shown in Figure 4(a). The peripheral beam could also be supported on stone corbels to avoid reduction of wall thickness of upper floor (Figure 4(c)). Timber struts were often adopted to reduce the span (Figure $4(\mathrm{~d})$ ). Common New Zealand URM constructions 


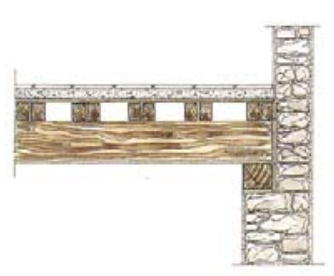

(a)

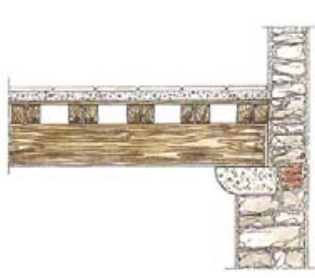

(b)

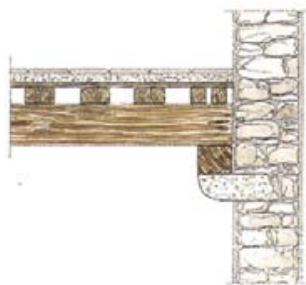

(c)

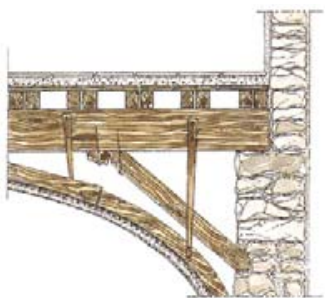

(d)

Figure 4: Examples of typical floor-to-wall connections [22]

built up until the 1931 Napier earthquake were typically cavity walls, with no rubble fill, supposed to be linked with steel ties. Details of such buildings were described by Russel et al. [3] highlighting that the floor/roof diaphragm pocket created in the masonry, in the other end, were shown by Cóias [33] and used to link the new timber headpiece in place of the degraded one (Figure 6(a)). Post-1755 Lisbon earthquake Pombalino buildings presented a much 
This paper can be found at https://doi.org/10.1016/j.engstruct.2019.109559

complex detailing if compared to other constructions of the same period: the timber floor joist would be connected to a top and bottom timber wall-plates embedded in the masonry wall, through carefully done cross-lap joints and the use of nails [34]. Metal straps were nailed to the timber joists and going through or into the wall. Effective floor to wall connection could be obtained making use of a $1 \mathrm{~m}$ long steel bar anchored to the masonry fixed diagonally to the timber joists in contact with it. The bar was usually embedded in the timber joists covered by the timber plank (Figure 5(b)).

It was common to cover large span using timber roof because of the availability of the material and easy manufacturing. A good rule to improve the mechanical characteristic of its connection to the masonry was to use steel strap infixed inside the wall and connected to the bottom horizontal member (Figure 5(c)). The steel strap could also be fixed to a bended bar which was used also to improve the connection between the chain and the rafter. A timber truss seated on a concrete padstone was shown in NZSEE, part C8 [35].

The use of horizontal metal tie-bars is common in heritage buildings to control the horizontal thrust exerted by vaults and arches or by wooden truss roof, but it is also one of the simplest and widespread solutions on new and retrofitted constructions ensuring the box-type behavior connecting the walls at floor levels $[36,37,38]$. Metal tie-rods in the pre-industrial age were forged steel bars in pseudo-circular or quadrangular sections anchored to the bearing structure and inserted with minimum tensile action. Usually, anchor plates or simply bars, forced into the eye-end of the tie rod with the help of metal wedges, restrained the bar, acting on the outer surface of the wall. 


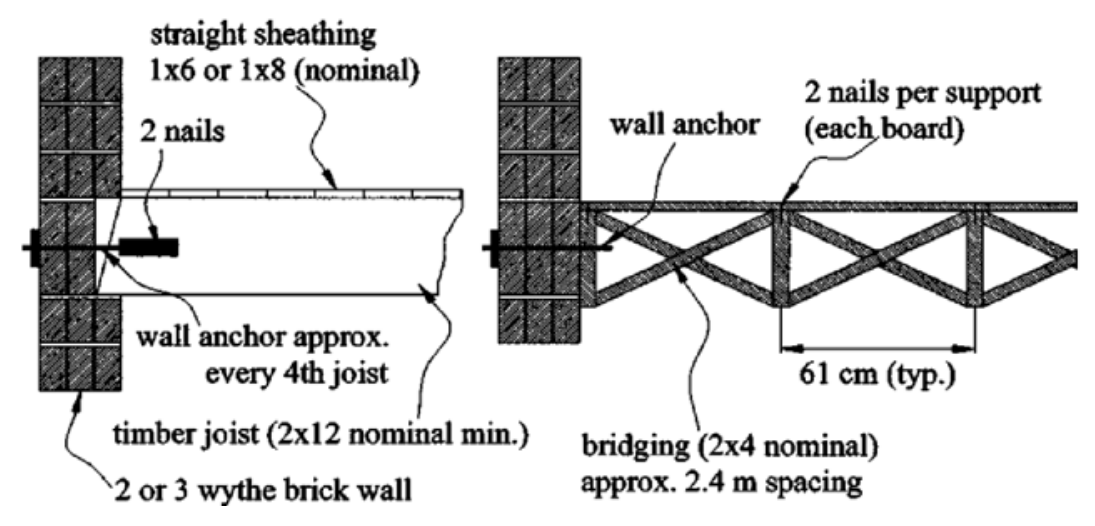

(a)

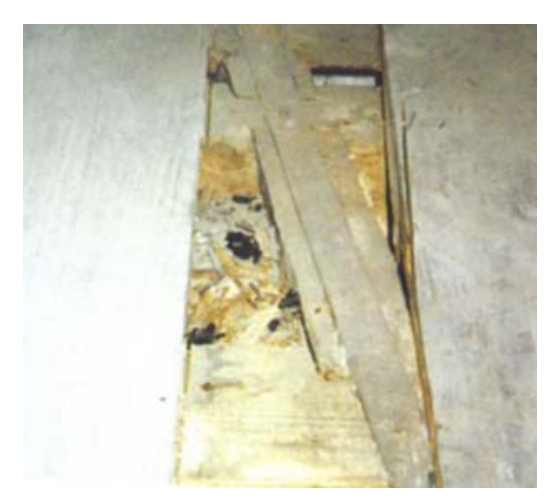

(b)

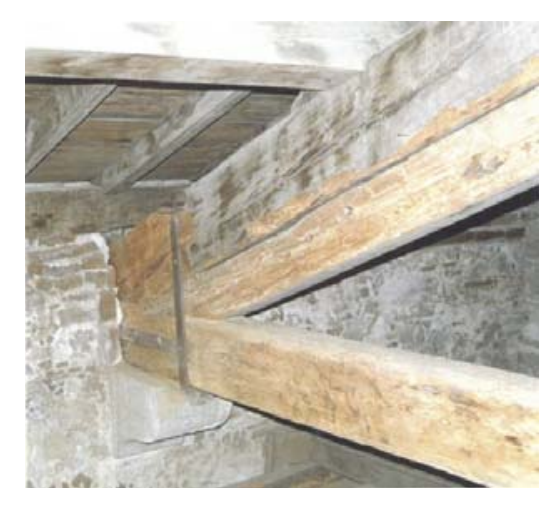

(c)

Figure 5: Metal anchorages between timber beams and masonry wall: (a) connections between the parallel or perpendicular joist and the wall [32]; (b) diagonal bar embedded into the transversal joists [34] ; (c) roof-to-wall connection [33] 

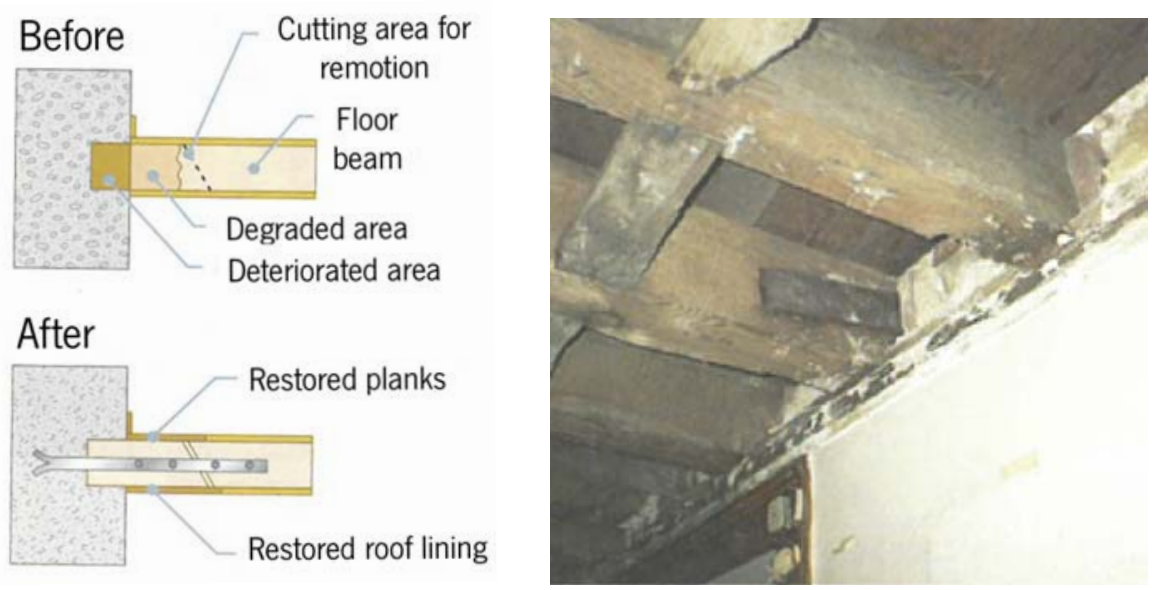

(a)

(b)

Figure 6: Timber to masonry anchors [33]: (a) Degrade timber joist headpiece replacement; (b) iron strip from the inside

A typical Mediterranean early 20th century floor, known as jack arch system (Figure 7), comprised iron beams supporting shallow brick masonry arches [6]. Here the metal beams were simply infixed in masonry slots and, sometimes, steel bars were present to reduce horizontal forces.

The arrival of reinforced concrete (RC) almost totally substituted masonry as main structural material for constructions, the latter being used

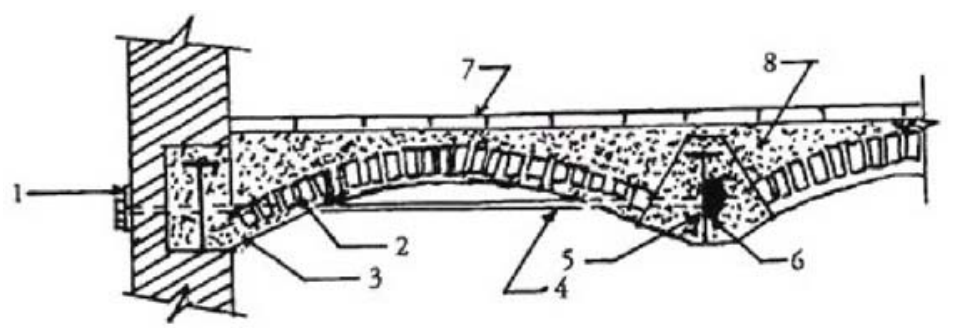

Figure 7: Jack arch roof: 1. M.S. plate $10 \mathrm{~mm}$ thick; 2. Brick arch; 3. Plaster; 4. M.S. Tie rod; 5. R.S.J.; 6. Cement concrete; 7. Flooring; 8. Lime concrete 
This paper can be found at https://doi.org/10.1016/j.engstruct.2019.109559

merely for infill walls or non-structural components, such as partitions or aesthetic façades. The presence of RC bond-beams (tie beams) in newly masonry buildings at floor levels allowed the requested connection between the slab (usually made of RC) and the walls. This allowed the transfer of horizontal forces from the floor to the cross walls and improved the IP rigidity of horizontal floor diaphragms [7].

\section{Seismic strengthening techniques}

Among the general technical criteria for a successful strengthening of masonry buildings in seismic areas, there is proper geometrical layout of structural walls, their sufficient load bearing capacity, regularity and symmetry, adequate foundation capable to transfer loads to the soil. In addition, it is well recognized that the walls should be adequately tied and connected to each other, and the floors should be well anchored to the walls preventing OOP collapses [7]. The latter criterion provides the structural continuity between different components and improves the capability of the building to dissipate energy through the introduction of newer ductile elements, which can improve the seismic response. In addition, not only the joist slipping is avoided, but anchoring the diaphragm to the wall prevents hammering, typical in historical constructions where the vertical and horizontal elements natural frequencies are uncoupled. Moreover, the selected solutions should be simple and economic, experimentally characterized and should fulfill the basic requirements of restoration and conservation of cultural heritage (in the case of historical monuments) [39, 40, 41].

The use of metal tie-bars is a very simple and widespread intervention 


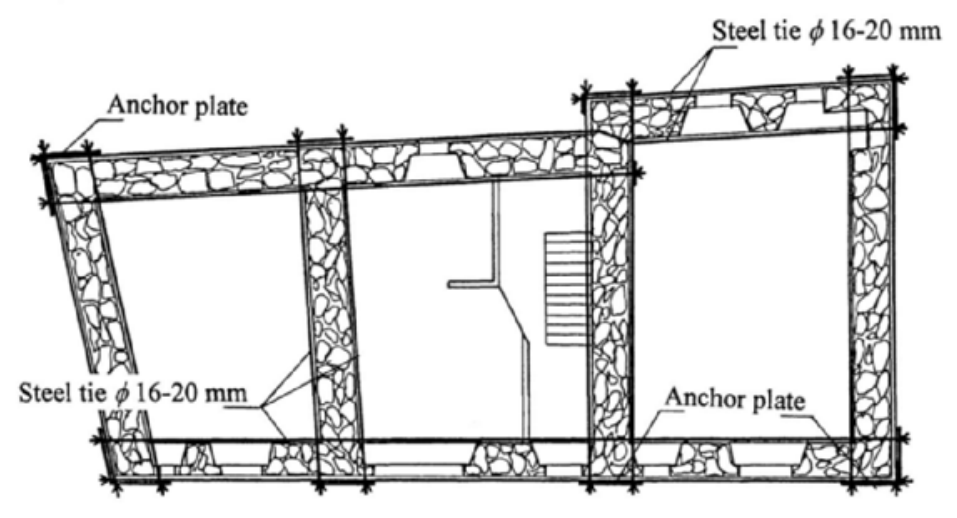

(a)

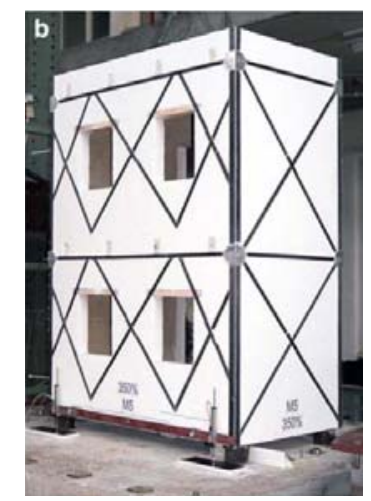

(b)

Figure 8: Tying URM walls for a seismic reinforcement: (a) Steel tie rods retrofitting [7]; (b) CFRP laminates retrofitting [44]

technique for the seismic upgrade of the URM building improving its structural integrity [36], useful both for semi-rigid and flexible floors such as vaults [42]. Typically, $16-22 \mathrm{~mm}$ diameter reinforcing steel slightly prestressed bars are placed at the floor levels on each side of the walls, anchored at the ends to steel anchor bars or plates (Figure 8(a)). However, as highlighted by Tomaževič [43], tying the walls is sometimes not sufficient for providing adequate structural integrity, and existing wooden floor structures should be strengthened, anchored and connected with masonry walls. Furthermore, the prestressed force must be conceived, designed and executed carefully: despite the masonry shear force increases with the compression level, the pre-tension induces alterations in the equilibrium of the structure and modifies the tension state of the masonry [34]. Recent suggestions for tying the masonry walls include the possibility to replace the steel ties with reinforced polymer laminates (Figure 8(b)), significantly improving the resistance and the lateral 


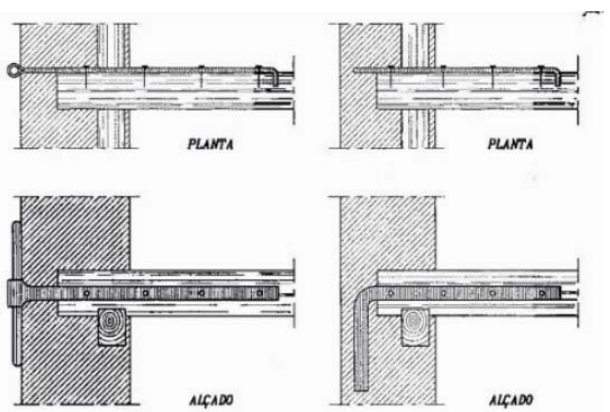

(a)

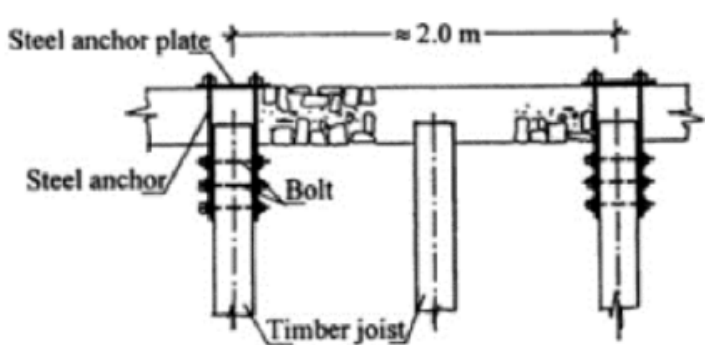

(b)

Figure 9: Wall-to-floor strengthening solutions: (a) wrought iron straps [33]; (b) double anchor system [7]

capacity, confining the building with vertically and horizontally placed strips $[43,45,46,47]$. For the latter solutions, precautions must be undertaken to face the great difference in strength and deformability between traditional masonry and innovative polymer, adopting compatible technologies for the bond and the anchoring system.

One of the first solutions used to improve the connection of the joists to the wall makes use of iron straps nailed to the timber joist and fixed into or through the wall, anchoring on the exterior face with simple iron bar, squared, star shaped, or circular plates [33], as shown in Figure 9(a). Figure 9(b) illustrates a strengthening solution proposed by Tomaževič [7] with double steel anchors aligned with the axis of the floor joist avoiding eccentricity. Blaikie and Spurr [48] described some retrofitting practices adopted after the 1931 Hawke's Bay earthquake, in New Zealand. Many of them include the installation of wall-floor and wall-roof connections, mainly through bolt anchors, used in conjunction with a steel bearing plate located on the exterior of the building and a bolted connection on the timber diaphragm 


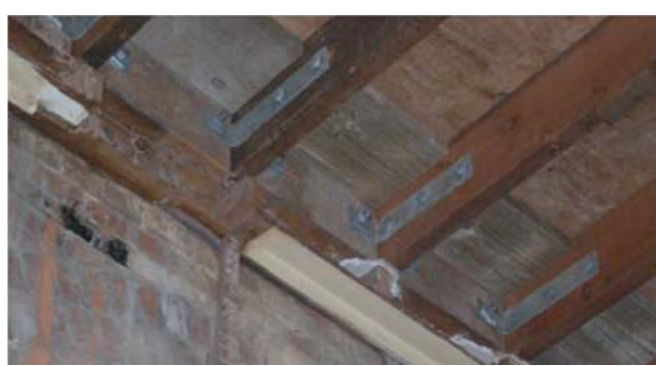

(a)

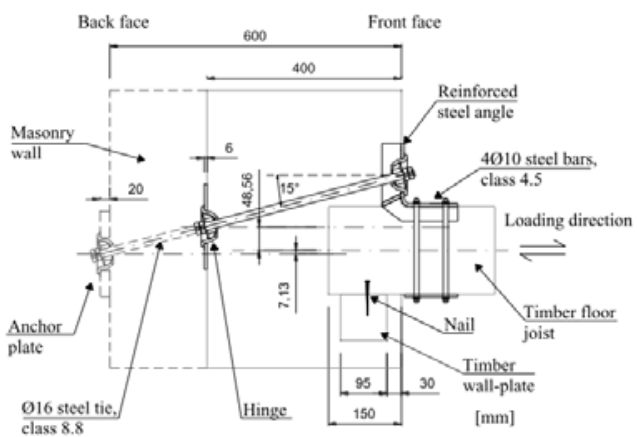

(b)

Figure 10: Wall-to-diaphragm bolt anchorages: (a) steel rods bolted to steel angles [48]; (b) innovative solution studied by Moreira [49]

joist, usually interconnecting a steel angle plate (Figure 10(a)). The bolted connections increase the shear resistance and improve the pull-out behavior of the solution. Newer interventions, studied by Moreira [49], contemplate hinges at both ends of the anchor allowing for a diagonal fixing of the tie directly from the top of the floor (Figure 10(b)), reducing the eccentricity and acquiring a more cost-effective solution. Cóias [33] proposed different strengthening solutions including injection anchors, where the grout injection controls the bond behavior between the steel tie and the surrounded masonry. Such a solution (Figure 11) requires access only from one side of the wall, facilitating the possible interventions on the façade or party walls. The connection to the timber joist is usually ensured by a bolted steel angle.

With respect to traditional steel anchors, dissipative passive systems may be integrated to improve the energy dissipation capability of the connections and may be based on the plasticity of the steel or on friction $[50,51]$.

Horizontal diaphragm action on floors or roofs is usually very poor in 


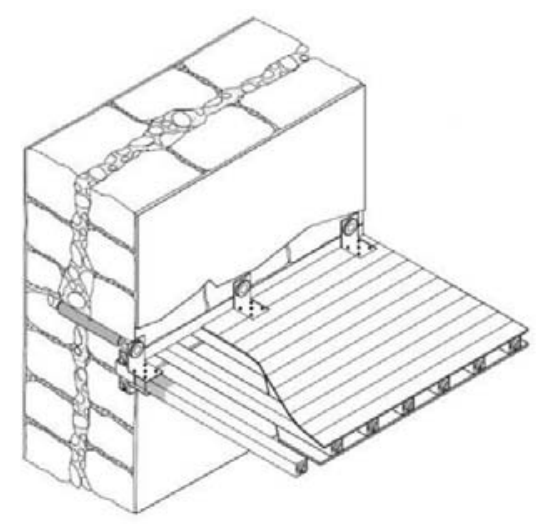

Figure 11: Strenghtening solution proposed for Pombalino buildings [33]

existing URM buildings because of the high flexibility of the diaphragm in comparison with the lateral resistant masonry walls. To increase their IP stiffness, timber floors or roofs are often replaced by RC or precast slabs with perimeter bond-beams similarly to the modern masonry constructions where the $\mathrm{RC}$ ring beams provide the connection between the $\mathrm{RC}$ slab and the wall so that the structural system performs as a monolithic unit during an earthquake. If the bond-beams are not completely embedded in the masonry, the slabs should be adequately anchored to the walls as shown by Tomaževič [7], see Figure 12. However, using RC slabs and ring beams should be considered as the last option as the increasing mass could lead to unfavourable high seismic inertia forces, which can cause OOP modes and produce torsional effects. Effective solutions can be achieved by overlapping a second timber deck anchored to the existing one and providing proper connections between the joists and the walls, with or without steel tie rods $[52,53]$.

The ring beam also increases the IP stiffness of the floor behaving as diaphragm chords [54] (Figure 13(a)) whose force can be computed considering 


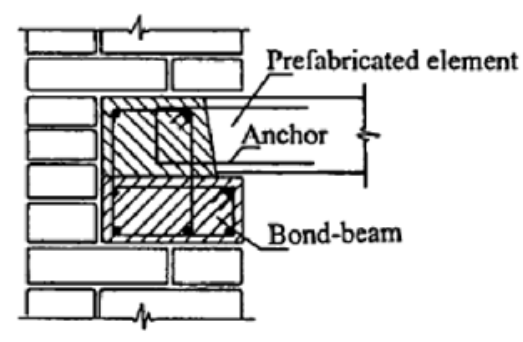

Figure 12: Connection between new RC bond beam and exsisting floor [7]

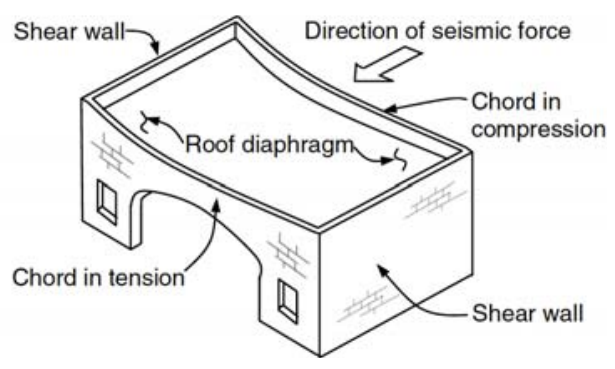

(a)

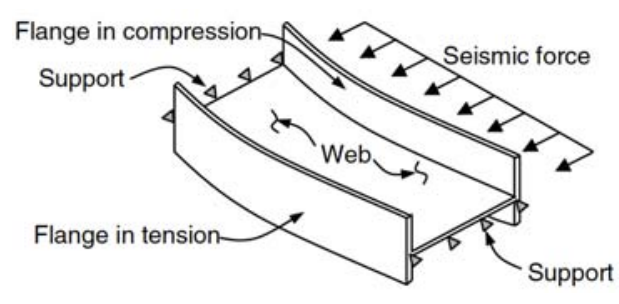

(b)

Figure 13: Chords and diaphragm corresponding to flanges and web [55]

the system (chords + diaphragm) as an I-beam under bending and shear in the direction of the earthquake (Figure 13(b)). Solutions shown in Figures 9, 10 and 11 are not usually able to perform as a diaphragm chord element, as they were designed mainly for the prevention of the shear and axial failure caused by IP and OOP forces, respectively. A chord strengthening solution is proposed by Hsiao and Tezcan [55] on the basis of FEMA [56]. The retrofitting strategy considers the strengthening of the shear and axial connections between wood diaphragms and URM bearing walls, following the concepts of maintaining the original figure of the historic building (Figure 14). 


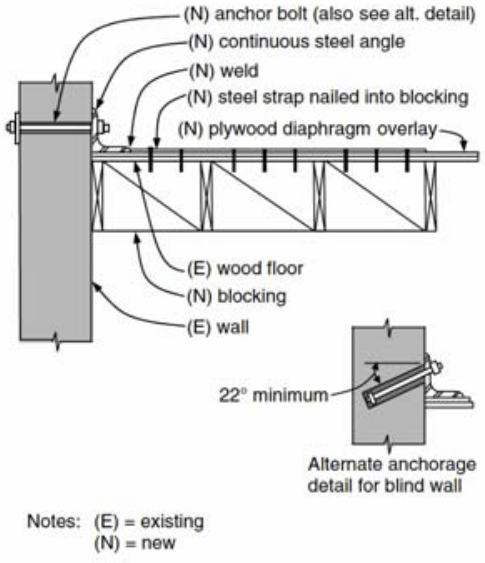

(a)

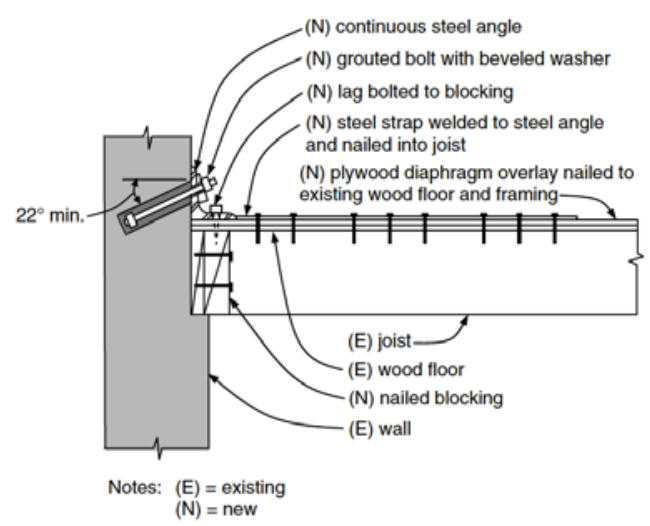

(b)

Figure 14: Chord strengthening connections [55]: (a) OOP bolted connection parallel to wall; (b) injected connection with joists perpendicular to the wall

A seismic strengthening solution applied on an old and damaged church timber roof structure is shown in Figure 15(a). The main aim was to increase the diaphragm behavior without destroying the original inner aspect of the church. The solution included the replacement of old timber with new timber beams and the insertion of a steel truss. Particular attention was given to the connection of beams to the perimeter walls (Figure 15(b)). A lattice girder lying along the bearing walls functions as lower tie beam.

Figure 16 shows a solution called "Perimetro Forte" (strong perimeter), where steel anchors are injected to the perimeter walls and bolted to the floor in special steel clamps [58]. Reinforcing bars are seated onto the clamps longitudinally to the walls, and a reinforced cementitious slab of minimum $6 \mathrm{~cm}$ is laid over and anchored to the existing floor through steel bolted connectors. Such solution can be easily installed over a steel or RC floor achieving a reasonable weight-to-stiffness ratio. 


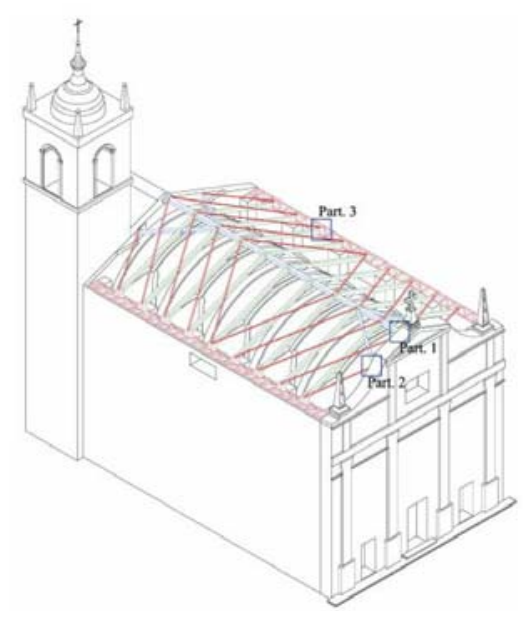

(a)

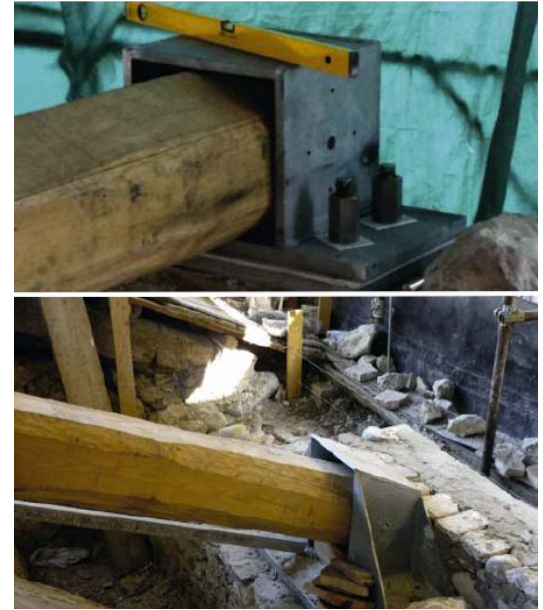

(b)

Figure 15: Seismic strengthening of a timber roof of a monumental building [57]: (a) Insertion of the truss system; (b) details of timber beam-to wall links

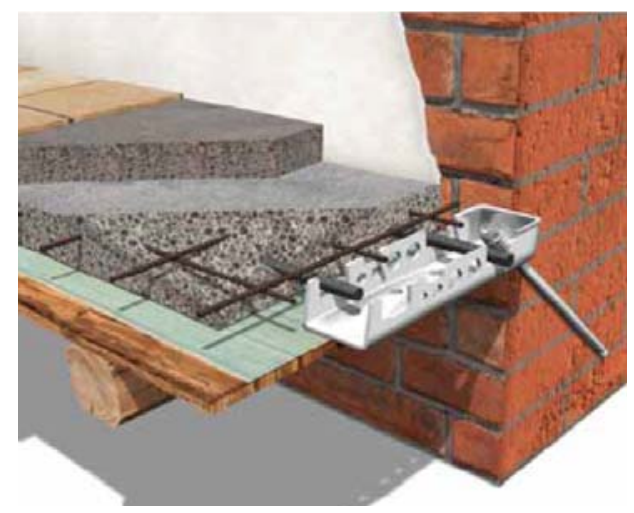

Figure 16: Strengthening solution recently developed by Leca Laterlite S.P.A. [58] 
This paper can be found at https://doi.org/10.1016/j.engstruct.2019.109559 the story drift to define different performance levels for URM buildings in performance-based design approaches. 


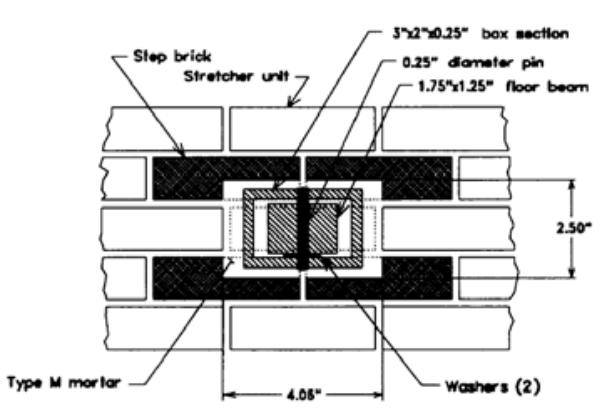

(a)

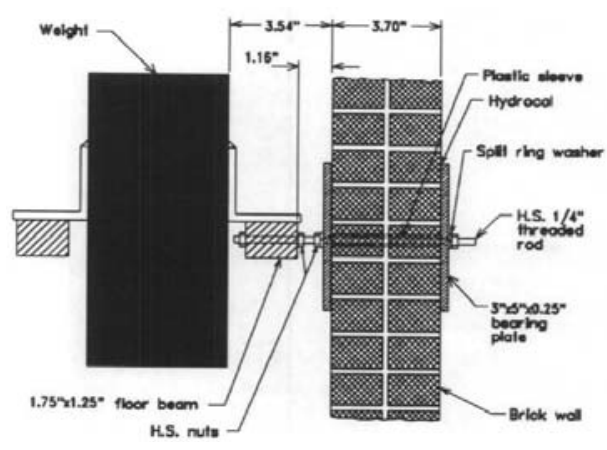

(b)

Figure 17: Shake table tests on reduced-scale URM building [60]: (a) front view of floor beam-to IP wall connection; (b) section of floor beam-to OOP wall connection

Bothara et al. [61] and Magenes et al. [59] performed shake table tests on half-scale and full-scale brick and stone masonry buildings, respectively, with conventional timber floor and roof, representative of existing URM dwellings. The incremental dynamic motions in both experimental campaigns indicated OOP response of portions of the walls perpendicular to the shaking direction, especially in top story zones, in agreement with observations on similar buildings stroke by real seismic events.

A shake table experimental program carried out at EUCENTRE aimed at studying the effectiveness of improved wall-to-floor and wall-to-roof connections through comparison with the unreinforced homologous prototype $[62,53]$. Strengthening interventions included, among the others, the activation of steel tie-rods; the use of L-shaped steel beams at floor levels bolted to external steel plates; the adoption of steel through bars connected to the perimeter masonry walls and embedded into a lightweight $\mathrm{RC}$ slab cast above the existing floor; reinforced masonry ring beams employed at 


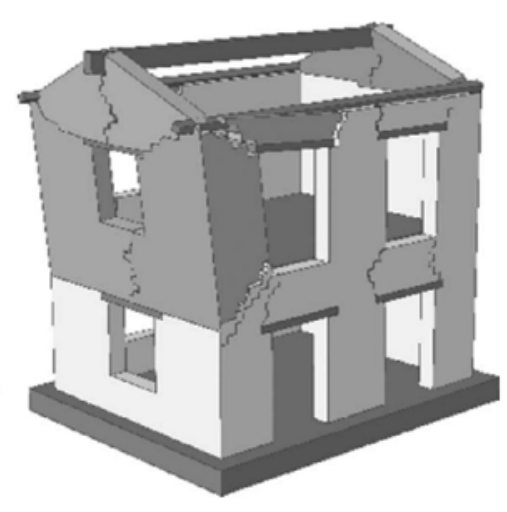

(a)

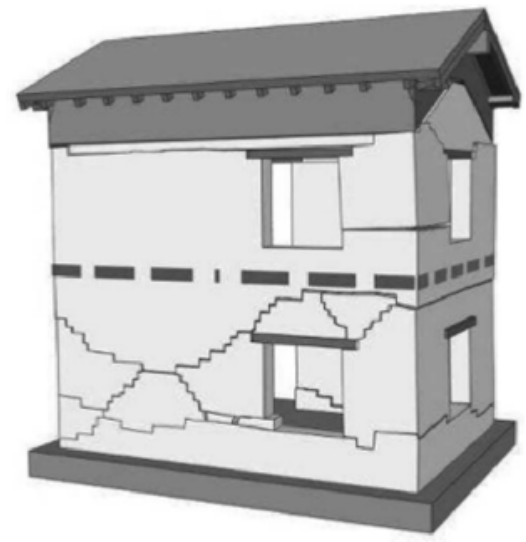

(b)

Figure 18: Shake table tests on full-scale URM buildings performed at EUCENTRE [62]: (a) illustration of OOP mechanism on unreinforced building under nominal PGA of $0.4 \mathrm{~g}$; (b) illustration of shear failure modes on reinforced prototype under nominal PGA of 0.7 g roof level. As shown in Figure 18, the applied strengthening techniques have clearly improved the behavior of the buildings activating IP mechanism of lateral resisting walls, typical of effective box-type buildings. However, from global experiments, the detailed mechanical characteristic of the connections was difficult to identify, therefore, local tests were needed. Further numerical analyses were recommended to evaluate different scenarios through calibrated models.

Three-leaf URM building models have been studied by Vintzileou et al. [63] through half-scale shake table tests. After initial shake, the damaged model was retrofitted (the timber floor was stiffened and accurately linked to the wall, reinforced through hydraulic lime based grout injections) to study the effect of widely applied intervention techniques. The wall-to-floor 
reinforcement was made by connecting the stiffened deck to the masonry with steel plates and grouted bar bolted each other. The selected scheme of interventions was very efficient, and it made the model able to sustain strong input motion, relying on the injections to enhance the OOP resistance of the external masonry leaf and its mechanical properties.

Dazio [64] investigated the effect of different top and bottom boundary conditions ranging from fully fixed to simply supported, on the OOP behavior of the URM brick wall, applying different levels of initial axial load and varying the wall slenderness. Shaking table test results showed that boundary conditions could have larger effect on the lateral stability of a URM wall then its slenderness, and it was observed that simply supported walls could reach higher displacement capacity in comparison to the restrained one.

Simsir et al. [65] performed a shake table test set-up to investigate the response of OOP wall component as an integral part of the building system, where the floor mass was supported on the walls by means of a pin connection, while timber diaphragm (floor or roof) was simulated using different steel profiles connected to the walls through almost perfect pin connections. Mid-height collapses of the wall resulted only for low level of axial load and significant mass of the wall, corresponding to upper floors in real buildings. The authors measured peak acceleration values at the top and mid-height of the wall up to 4.5 times the peak base accelerations. In this study, the influence of adjacent IP walls and the deformability of the diaphragm-to-wall connection are neglected. 
This paper can be found at https://doi.org/10.1016/j.engstruct.2019.109559

\subsection{Wall-diaphragm anchor tests}

Accurate accounting for the connections into the numerical model requires their mechanical static and dynamic characterization and this is not usually obtained or addressed after shake table tests on building or local wall scale. Detail-scale experiments (pull-out or shear tests) can be useful to address this problem aiming at force-displacement curves of existing or improved/repaired prototype connections.

In New Zealand the dynamic behavior of two types of URM walls anchors was performed by Jacks and Beattie [66]. Both through-bolt and epoxiedin anchors were investigated through pull-out tests. From the dynamic and static tests of the through-bolt anchors, no pull-out failure of the URM panel was observed even under high load levels (96kN of dynamic and $200 k N$ of static loads) indicating the effectiveness of the practice for anchoring URM walls. From the static tests of the epoxied-in anchors, the anchorage failure was related to the crack occurred across the full width of the test panels.

Lin and LaFave [15] conducted static monotonic, as well as static and dynamic cyclic tests on two different types of typical brick wall to wood diaphragm connection specimens, with and without nailed strap anchors (Figure 19(a)). The authors considered the contribution of friction and of strap anchor nails loaded in shear separately and together. A value of friction coefficient was suggested as the average measured, well compared with historically published values. The behavior under dynamic cyclic loading was more brittle than behavior under monotonic or quasi-static cyclic loading, for the case of connections with nails and friction (Figure 19(b)). Results obtained from those tests can be used to calibrate nonlinear finite element 


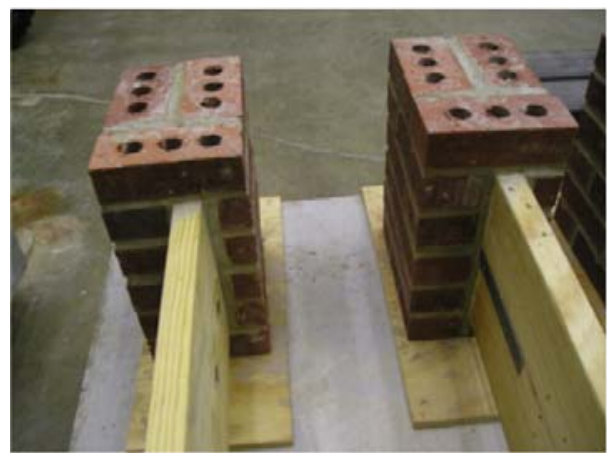

(a)

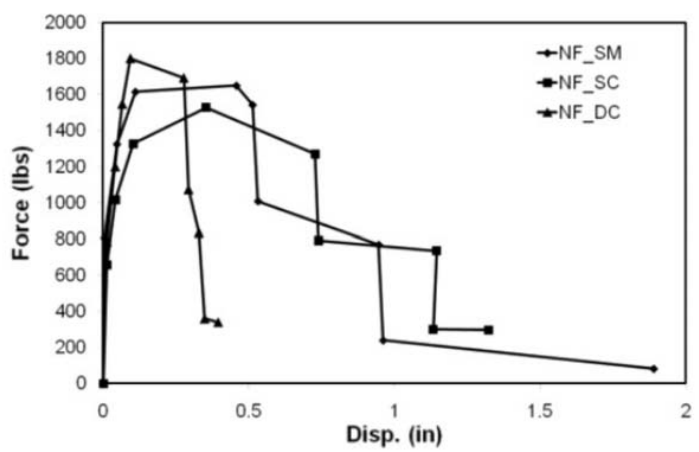

(b)

Figure 19: Experimental campaign performed by Lin and LaFave [15]: (a) test specimens of wall-diaphragm connections; (b) comparison between static monotonic (SM), quasistatic cyclic (SC) and dynamic cyclic (DC) average curves, considering the contribution of friction and nailed straps $(\mathrm{NF})$

models of these types of connections.

Campbell et al. [67] studied typical existing wall-diaphragm anchor plate connections, extracted post-earthquake by sorting through the demolition debris from URM buildings damaged in the 2010 M7.1 Darfield (Christchurch) earthquake. The connections consisted of long, roughly $25 \mathrm{~mm}$ diameter rod, with a rectangular or circular steel plate (about $5 \mathrm{~mm}$ thick) attached to the wall end that is about $50 \mathrm{~mm}$ wide $x 450 \mathrm{~mm}$ long and fastened to the rod and positioned either inside the brick wall or in the center of a masonry pier or wall (Figure 20(a)). The authors established at least seven plausible failure modes associated with the wall-diaphragm anchor plate connections that were axially loaded to rupture (Figure 20(b)) (A. Punching shear failure of masonry; B. Yield or rupture of connector rod; C. Rupture at join between connector rod and joist plate; D. Splitting of joist or stringer; E. Failure of fix- 


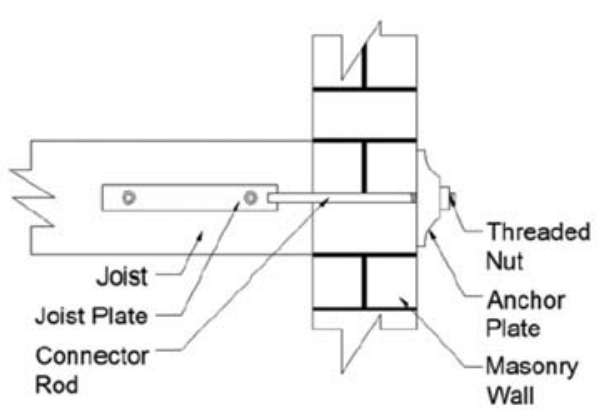

(a)

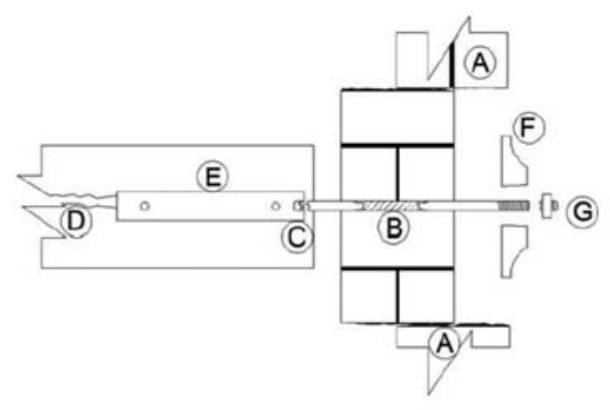

(b)

Figure 20: Typical New Zealand wall-diaphragm anchor plate connections [67]: (a) connection assembly; (b) location of failure modes

ing at joist plate; F. Splitting or fracture of anchor plate; G. Yield or rupture at threaded nut), based on 2010/11 Canterbury earthquake sequence damage observations and on a small amount of anchor samples tested (only six anchor plate connections). A lower $5^{\text {th }}$ percentile characteristic ultimate tensile strength of $63.9 \mathrm{kN}$ was suggested for connections having anchor plates of approximately $200 \mathrm{~mm}$ diameter and connector rods of approximately $17 \mathrm{~mm}$ diameter. For degraded connections a $5^{\text {th }}$ percentile characteristic ultimate stress of 269.5 $\mathrm{MPa}$ was recommended, but further testing to be undertaken was suggested to increase the test dataset.

Karim et al. [68] studied experimentally the wall-diaphragm connection focusing on the failure of the timber joist bolted connection. They recommended a set of design equations to assess the strength of the connection related to the minimum strength value that will govern the capacity of the whole connection. This procedure could quantitatively and quickly assess the performance level of wall-diaphragm connection, which could be reinforced, 


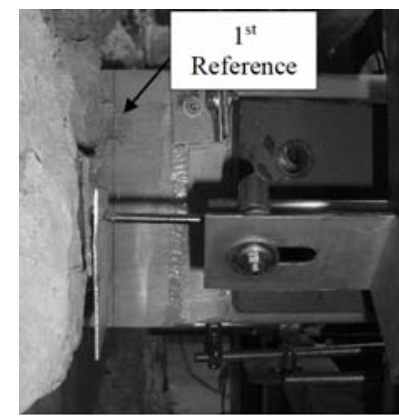

(a)

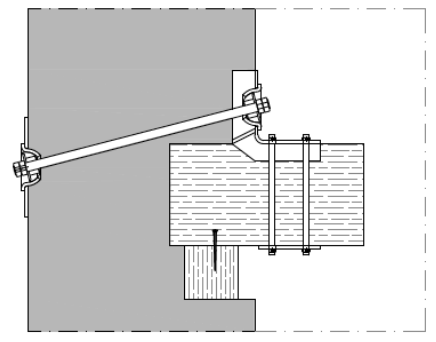

(d)

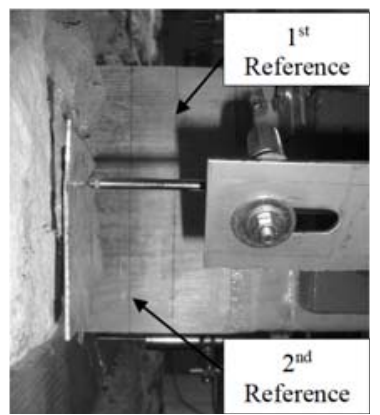

(b)

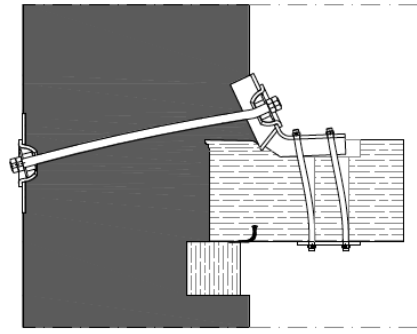

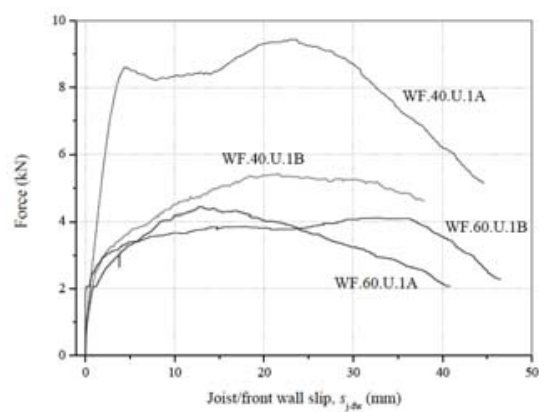

(c)

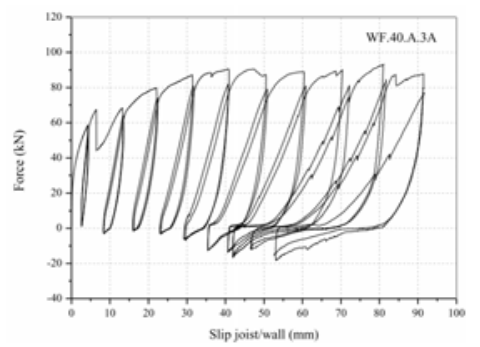

(e)

Figure 21: Experimental campaign performed by Moreira [49]: (a) and (b) sliding of the timber joist caused by failing of nails before and after; (c) monotonic force-displacement curve of unstrengthened specimen; (d) deformation of pulled-out strengthened specimen; (c) cyclic curves for strengthened tests

if necessary.

Moreira [49] carried out an experimental campaign on both unstrengthened and strengthened wall-to-floor connections typical of late $19^{\text {th }}$ century in Lisbon. The strengthened connection relied on anchoring the timber floor to the masonry wall through the use of steel tie-rods with anchor plates. Hinges at both ends reduced the bending force induced by the timber beam to the anchor, diagonally infixed into the masonry (Figure 10(b), Section 3). Both quasi-static monotonic and cyclic pull-out tests were carried out. In 
This paper can be found at https://doi.org/10.1016/j.engstruct.2019.109559

all unstrengthened specimens monotonic tests were performed and the two nails connecting the joists to the wall-plate failed causing clear sliding (Figure 21(a), (b)) and the capacity was highly influenced by the rotation of the joist. For the strengthened connections, yielding of the steel angle, crushing and shearing of the timber was observed (Figure 21(d)), and the tensile capacity of the connections was approximately 19 times greater than the one of the unstrengthened ones and the ultimate displacements were much larger by comparison. However, a decrease in ductility could be observed due to increase of the elastic limit and cyclic tests degradation (Figure 21(c),(e)). A retrofit design proposal was recommended for design at component level, and future works are necessary to establish hysteretic rules useful to implement the connection as an element in numerical models of whole buildings.

Ismail [69] tested 40 grouted/epoxied anchors for pull-out-capacity (POC) of which 30 were installed in salvaged heritage material assemblages and 10 in-situ at a heritage URM building. Two types of anchors were considered in this study: 1) helically shaped stainless steel $10 \mathrm{~mm}$ anchors; and 2) self-cutting stainless steel anchors with $12 \mathrm{~mm}$ diameter. The author investigated the influence of embedment length, installation quality, anchor location, condition of masonry and condition of substrate materials on anchor performance. The highest probability of failure during an earthquake is associated to the failure of anchor-diaphragm connection and thus limits the achievable POC of the wall to diaphragm anchorage system. However, this type of failure was observed to be reasonably ductile.

A consistent experimental campaign (almost 400 specimens) was undertaken by Dizhur et al. [70] on adhesive anchor connections between unre- 
This paper can be found at https://doi.org/10.1016/j.engstruct.2019.109559

inforced clay brick URM walls and roof or floor diaphragms. No conical masonry failure surface was observed in any of the tests. Cementitious grout was a suitable anchor adhesive and $16 \mathrm{~mm}$ anchor rod diameter was considered to be the optimum rod size for the POC of the adhesive anchor. Low overburden weight negatively influences the POC and accurate installation process is critical to achieving adequate POC. The authors proposed a design equation of the POC of adhesive anchors considering relevant parameters and based on the concrete breakout strength of an anchor in tension as proposed by Fuchs et al. [71]. No strength reduction factor is required, except when ultra-weak masonry, or particularly low overburden loads, are encountered.

Recently, Dizhur et al. [72] undertook experimental tests on original vintage wall-to-diaphragm plate anchor connections installed in an URM buildings, built in 1913. Two different types of anchorages between the masonry anchor and the timber diaphragm were studied: (i) metal connector directly fixed to the timber joist through a bolted joist plate (Figure 22(a)), and (ii) connections making use of timber blocking (vertical or horizontal timber elements interconnected between the joists) (Figure 22(c)). Failure modes and force-displacement curves were provided for the plate anchor, while ultimate capacity was established for the timber blocking systems with different configurations (Figure 22(b), 22(d)). Among the main outcomes from the experimental campaign results, authors highlighted that timber joist splitting was the most commonly observed failure mode for joist plate anchor connections, while positioning the timber blocking horizontally allowed the highest performance to be achieved. Finally, when a small washer was used, timber bearing failure was observed in timber blocking systems. 


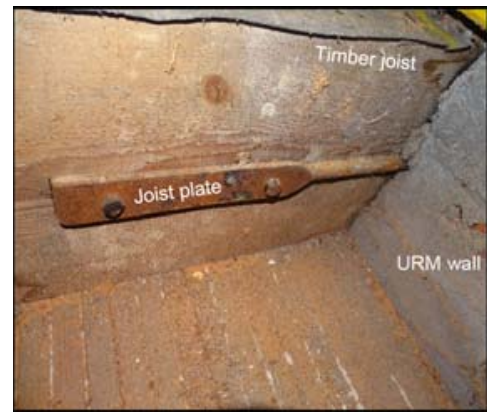

(a)

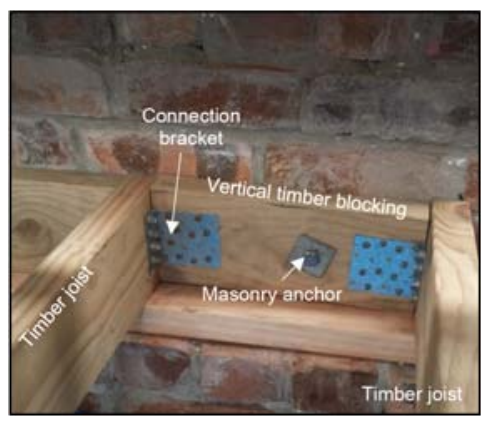

(c)

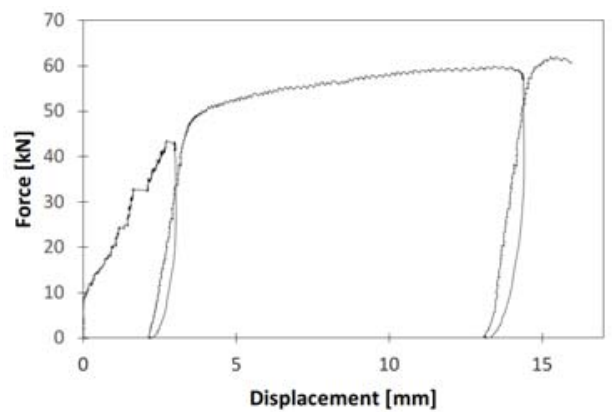

(b)

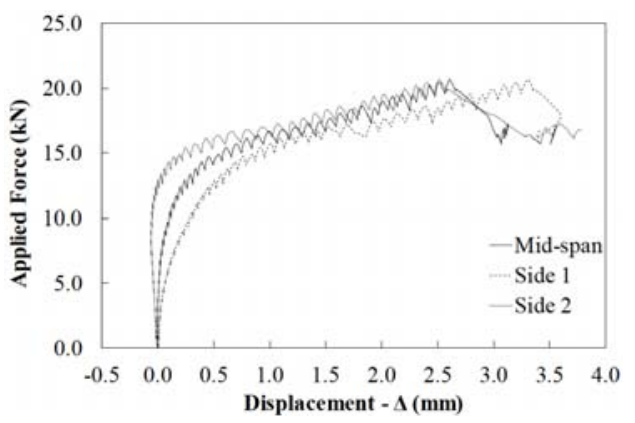

(d)

Figure 22: Wall-to-diaphragm experimental tests by Dizhur et al. [72]: (a) joist plate connection; (b) joist plate connection exhibiting anchor rod rupture; (c) timber blocking connection; (d) vertical timber blocking connection exhibiting screw withdrawal 
This paper can be found at https://doi.org/10.1016/j.engstruct.2019.109559

\section{Assessment approaches and code standards}

Basically, an existing URM building can be seismically assessed comparing its capacity $(\mathrm{C})$ to the seismic demand (D) through the following inequality:

$$
C>D \text {. }
$$

Different definitions of both the capacity and the demand lead to several approaches, which can be mainly grouped into two big families: force-basedapproaches (FBA), and displacement-based-approaches (DBA) [73, 74, 75]. Energy-based-approaches (EBA) were also recently proposed by Sorrentino et al. [73] and Giresini [76] as a promising tool, but still less conservative procedure for assess the seismic response of local OOP masonry walls, if compared to current code verifications. A considerable number of modelling techniques have been developed for the seismic analysis and assessment of URM constructions in a building scale [e.g. 77, 78] and local scale (i.e. OOP mechanism) [e.g. 73, 74], but only few included the behavior of the connections between vertical and horizontal members interfaces [e.g. 79, 65, 80]. Moreover, authors often considered the connection assuming simplified hypothesis (i.e. perfect hinges or linear elastic springs), neglecting the cyclic nonlinear behavior, typical for many typologies of links and reducing the number of the degrees of complexity of the dynamic problem.

The most common modelling techniques comprise rigid block approaches, numerical finite elements models (FEM), and distinct (or discrete) elements models (DEM). For rigid block approaches, the capacity can be computed through static or kinematic analysis, while the demand is usually derived from the displacement response spectrum, based on the period of the equiv- 
This paper can be found at https://doi.org/10.1016/j.engstruct.2019.109559

alent SDOF system. When NLTH analysis is used, however, the demand

475 motion leading to a certain level of damage or collapse. Static pushover and dynamic analysis with time-step integration under artificial or real accelerograms are common tools when FEM or DEM techniques are adopted [81, 82]. For the former analysis the capacity can be defined as the peak of the remodels, based on linear masonry behavior and flexible and linear diaphragms (elastic springs). Mainly two structures served as case-study (Figure 24), and 


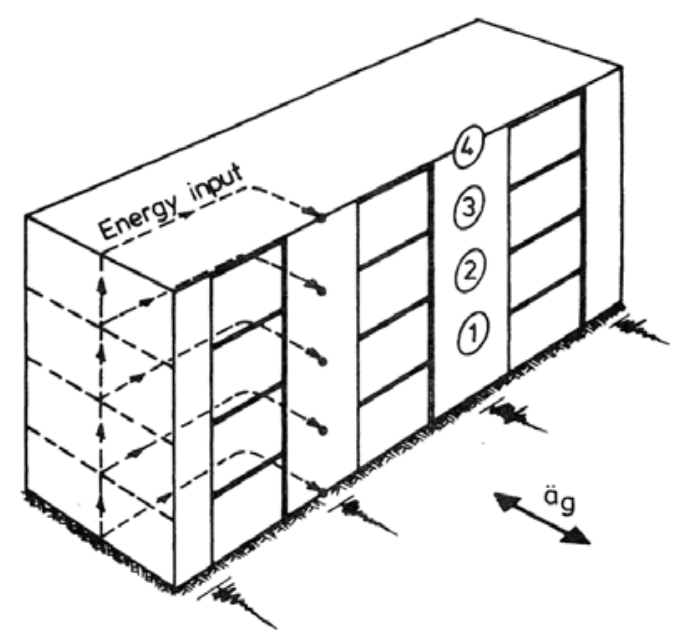

Figure 23: Seismic load path in URM according to Priestly [83]

results demonstrated that, in some cases, diaphragm and shear-wall accelerations can increase with the flexibility of the diaphragm. Moreover, torsional forces could reduce considerably as diaphragm flexibility increased. Finally, the authors stated that the period of vibration of systems with flexible diaphragms could be underestimated if calculated through approximate expressions prescribed in current seismic codes.

An unconventional procedure for the simulation of the OOP dynamic behavior of URM buildings, considering the stiffness of the roof, was performed by Costa [85], where the local mechanisms were modelled as kinematic chains of masonry portions (normally assumed as infinitely rigid bodies) whose nonlinear behavior is concentrated at the contact regions (Figure 25). The author considered a Coulomb-type sliding friction law and energy dissipation through the restitution coefficient at the impacts. Springs simulated the IP stiffness of the horizontal diaphragm. Lumped mass located at the ridge and 


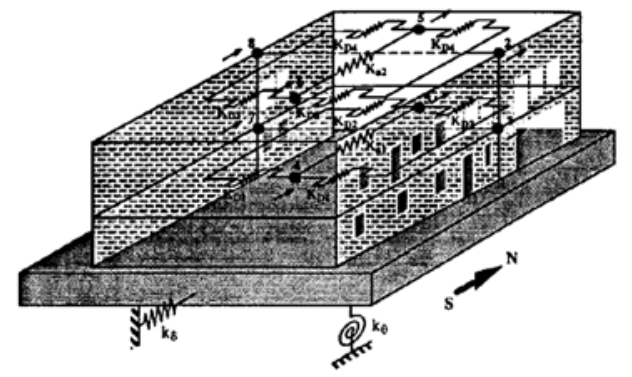

(a)

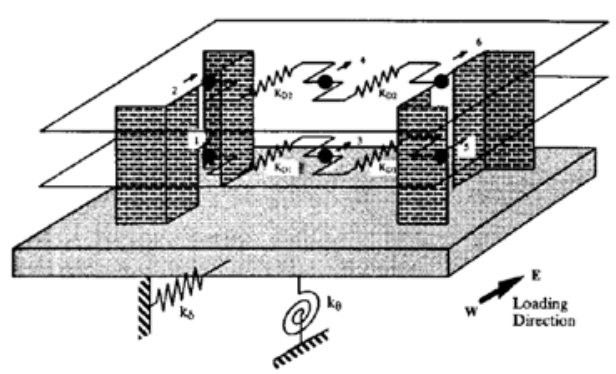

(b)

Figure 24: Modelling of buildings through discrete dynamic models by Tena-Colunga and Abrams [84]: (a) firehouse; (b) office building

top spreader beams represented the roof mass. Similarities of the method can be found in the modelling technique used by Oliveira et al. [86] based on DEM method for the interpretation of the post-seismic damage in URM structures. This methodology was adopted to simulate the experimental behavior of a full scale URM unstrengthened building tested at EUCENTRE (described in Section 4), for which elastic springs were placed at the top of each roof pitch (with a stiffness of $1.49 \mathrm{MN} / \mathrm{m}$ defined according to results obtained by Brignola et al. [1]). The adopted numerical approach allowed simulating the experimental failure mode with sufficient accuracy, but further studies were suggested to obtain an adequate and suitable method for the simulation of the OOP behavior of masonry walls. As highlighted by Ferreira et al. [74], the main advantages of such methodology rely on the time efficiency and the mechanical parameters (using only geometric parameters, mass, friction coefficient and restitution coefficient), while the predefinition of the formed local mechanisms need further analysis or judgement to define a realistic overturning mechanism, setting the limits and the drawback of the 

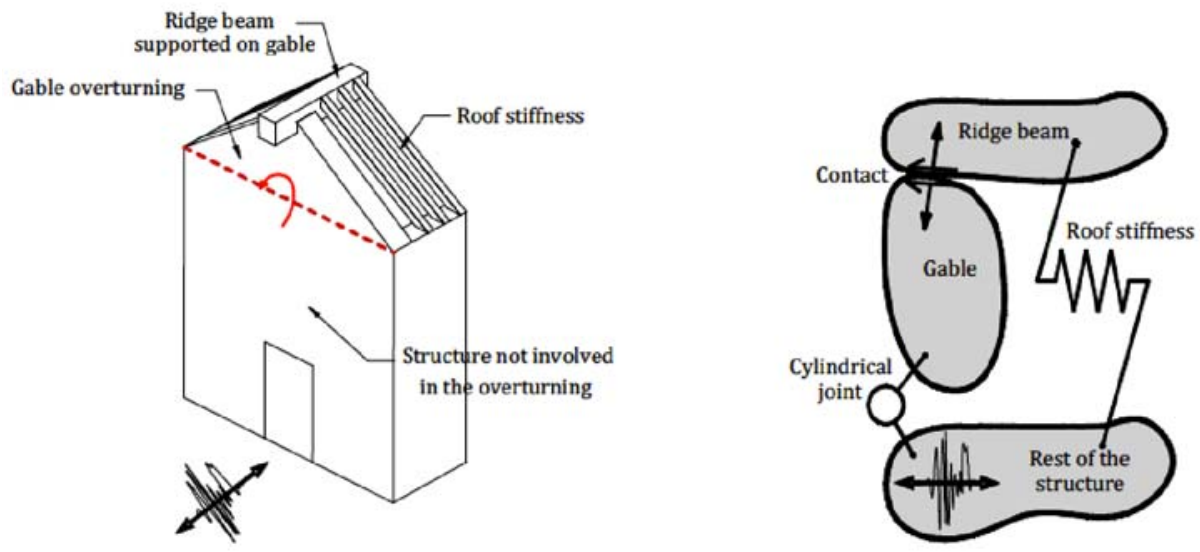

Figure 25: Schematic representation of the equivalent Multi-body dynamics-based approach [85]

method.

Ortega et al. [87] developed a parametric study through a detailed FEM and pushover analyses aiming at the evaluation and quantification of the influence of the type of diaphragm in the seismic behavior of vernacular buildings (Figure 26(a)). Among the different parameters that have been analysed, the connection between the timber beams and the walls, and the connection between the timber deck and the masonry were studied, considering different embedment and connection conditions. Results clearly showed the important increase in seismic resistance of the building if proper connections were adopted (i.e. timber beams fully embedded inside the whole thickness of the wall, and cross-board sheathing infixed in the walls), see Figure 26(b), avoiding the prematurely cone failure on the masonry and a better redistribution of the forces to the IP walls. The adoption of rigid diaphragms with low levels of connections between the timber beams and the walls resulted to be ineffective. Besides FE approaches is rarely adopted 


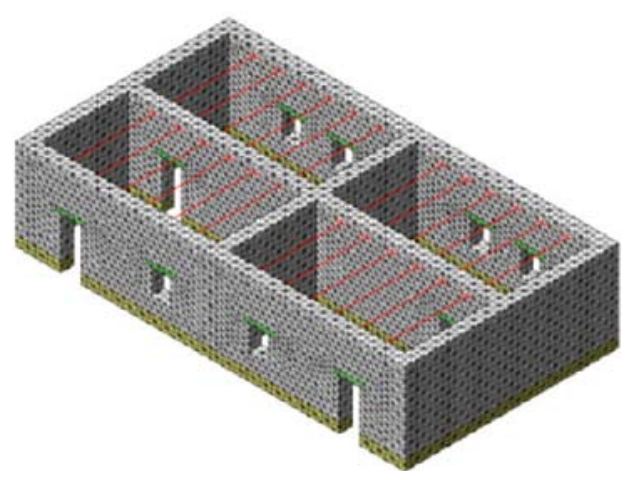

(a)

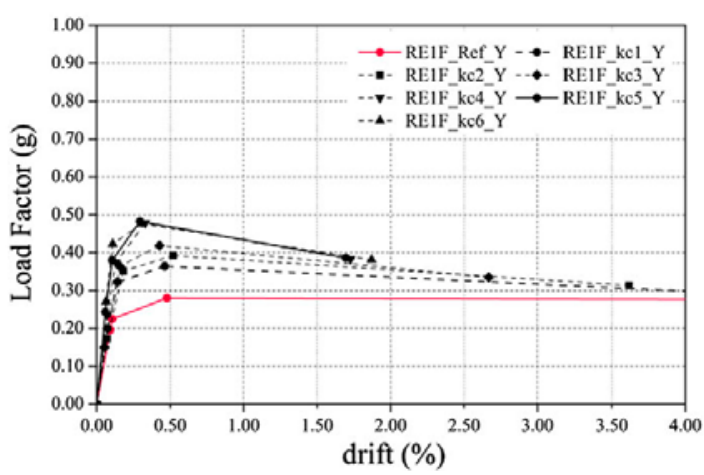

(b)

Figure 26: Detailed FEM developed by Ortega et al. [87] in order to evaluate the influence of beam-to-wall connection: (a) one of the three case study buildings; (b) positive influence of proper beams-to-walls connections

from practitioners for masonry constructions, several examples demonstrate its capabilities also for large complex structures [88]. Nonlinear mechanical characteristics of the masonry and flexibility of the floor are few of the important parameters playing a crucial role on the vulnerability index, usually obtained through pushover analyses [89, 90]. Because of the local behavior of structural elements, frequently observed in historical buildings due to the poor connections between each other, timber roofs or floors are often neglected as structural elements (included only as additional masses on top of the walls) [91]. When a good quality of the connection may be justified, the diaphragm timber beams can be included in the global 3D model, but the connection is usually perfect (acceptable only for properly retrofitted connections or new buildings).

Senaldi et al. [53] simulated the experimental results by using an equivalent frame approach implemented in the program TREMURI [92]. The 

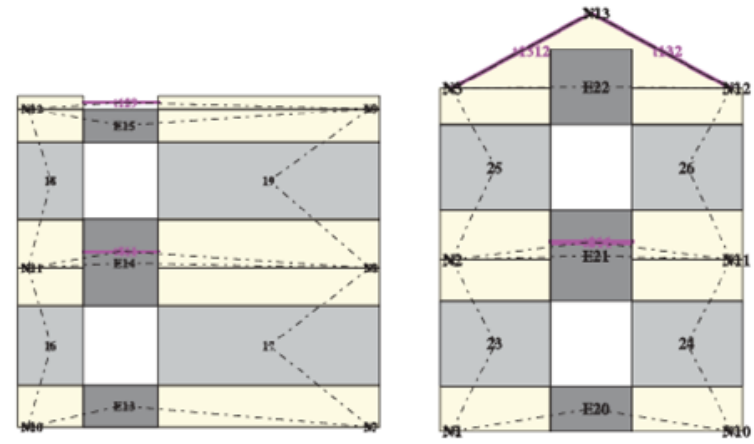

(a)

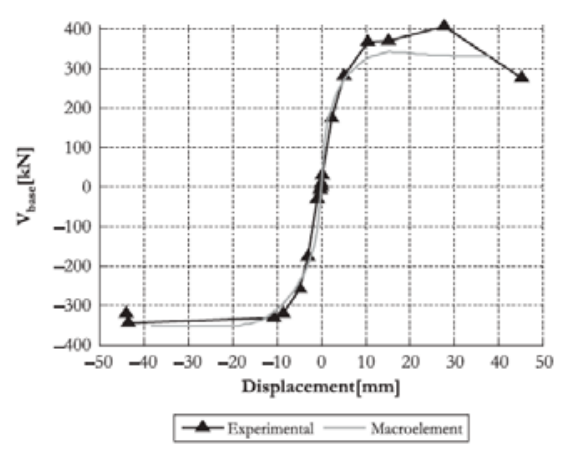

(b)

Figure 27: Experimental model implemented in TREMURI program [53]: (a) geometry of the model; (b) experimental vs. numerical pushover curves

macro-element model (Figure 27(a)) allowed for the shear-sliding damage evolution and rocking mechanism, with toe-crushing effect. Nonlinear beam elements have been introduced to account for the presence of the $\mathrm{RC}$ ring beam and of the wall to diaphragm connections at floor level. Pushover curves were compared to the experimental resistance curve, showing well similarities (Figure 27(b)). The equivalent frame modeling may be considered as a simplified approach, preferred by professional, for a first conservative approach for the seismic assessment of existing URM buildings. This approach, however, is not recommended for buildings with irregular opening patterns, high flexible floors and poor wall-to-floor and wall-to-roof connections [93].

A simplilfied modeling approach was presented based on three dimensional discrete elements as an extension of a plane macro-element [94]. The proposed approach lies in between the more complex, computationally cumbersome and more detailed nonlinear FE method and the classical limit approach and shows the capability of simulating the nonlinear response of mon- 
This paper can be found at https://doi.org/10.1016/j.engstruct.2019.109559

umental structures. The dynamic behavior of the structural connections is not usually taken into account.

575 5.2. Local scale approaches

Cross et al. [95] provided a useful tool for the design of seismic retrofit details developing a FEM that accounts for friction and impact behavior at the diaphragm-to-wall interface. The effectiveness of the model was demonstrated through comparison to some MDOF systems and applying this approach to a historic brick building shaken during the Loma Prieta 1989 earthquake.

The influence of strengthening techniques (e.g., insertion of tie-rods, of rigid diaphragms, etc.) was studied by Giuffrè [96] through a rigid-body limit analysis on a comparative basis. The safety check was given between the maximum horizontal load multipliers causing OOP mechanisms, and an expected PGA normalized to gravity. A response spectrum for the bilinear non-dissipative model was proposed allowing to evaluate the maximum displacement expected as function of the PGA and several parameters concerning the static strength of the model to horizontal forces. On the same bases, D'Ayala and Speranza [97] developed a simple but realistic mechanical model, based on post-earthquake damage observations, capable of handling a large number of buildings and performing statistical analysis. The model allowed to consider the influence of seismic strengthening (insertion of ring beams and ties), proving their efficiency, especially for slender vulnerable buildings. Several load factor equations were given for each overturning mechanisms (e.g. Figure 28) without and with the presence of strengthening devices (for which the arch effect was taken into account), and implemented 


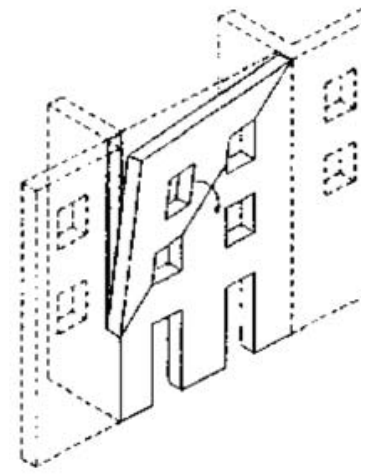

(a)

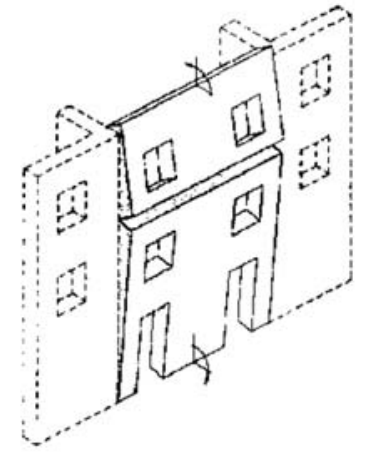

(b)

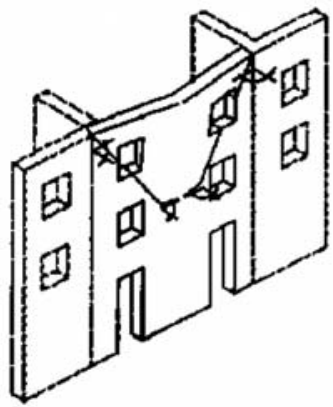

(c)

Figure 28: Mechanisms for overturning failures studied by D'Ayala and Speranza [97]

in the FaMIVE (Failure Mechanism Identification and Vulnerability Evaluation) procedure for the online evaluation of a façade or building seismic vulnerability.

Lawrence and Marshall [98] proposed a new approach for the design of masonry OOP panels based on the knowledge of the likely crack lines, through application of virtual work principles. A design equation was given for different boundary conditions (the top of the masonry panel was considered either free or simply supported) and results were compared with several tests available in literature providing closer estimates with low variability. The method also allowed for the presence of door and window openings.

A two-degree-of-freedom model was introduced by Simsir et al. [65] as an assemblage of two rigid bars interconnected by rotational springs, simulating the cracked wall tested experimentally. The connection on the top was modelled as elastic spring representing the stiffness of the IP wall and the diaphragm connected in series (Figure 29(b)). The authors also compared a SDOF (Figure 29(a)) to a MDOF (Figure 29(c)) model to study the influ- 


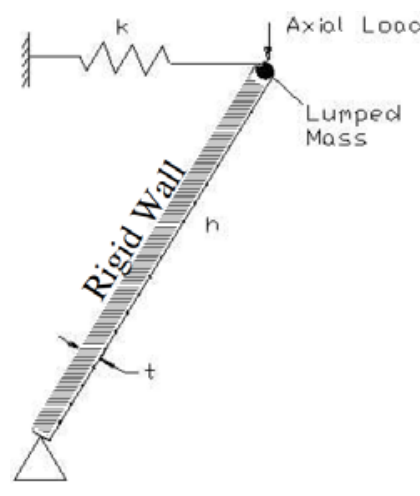

(a)

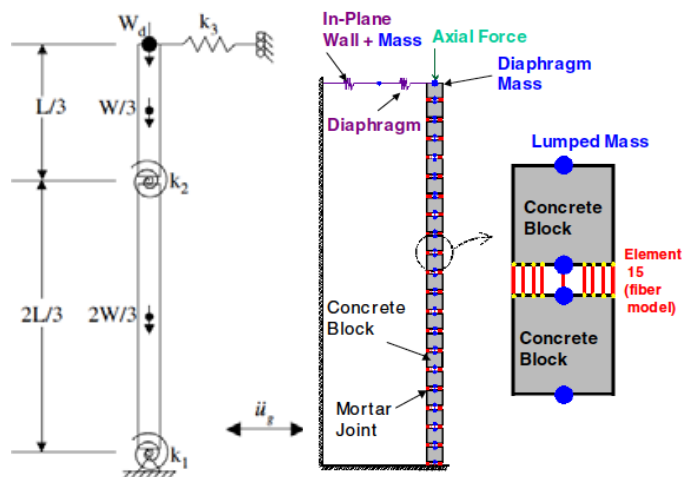

(b) (c)

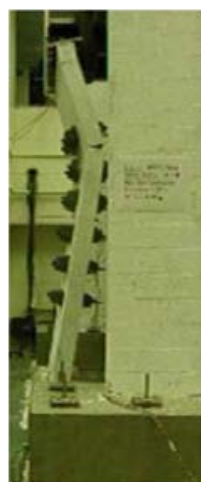

(d)

Figure 29: Numerical and experimental studies carried out by Simsir et al. [65]: (a) SDOF model; (b) 2DOF model; (c) MDOF model; (d) damaged specimen after tests

ence of OOP bending caused by cracks at the bed joints. The SDOF model seemed to be inaccurate if compared to MDOF, as could not capture higher mode response observed experimentally (i.e. it could not model the formation of the mid-height wall crack as shown in the experimental test result in Figure 29(d)), while the two-degree-of-freedom model revealed to be a simple and efficient tool for the evaluation of the seismic vulnerability of OOP walls showing sufficient experimental validation.

When a monolithic behavior is a reliable assumption for the walls in OOP, they can be regarded as rigid blocks, and possible reliable approaches can be rocking and kinematic dynamics analysis simulating the local behavior.

Basis on rocking blocks can be found on the pioneering work of Housner [99], who considered the motion of a SDOF free rigid block, a rigid prism with longitudinal rectangular cross section, rocking about the two corners $\mathrm{O}$ and O' (Figure 30(a)) subjected to free vibrations, constant and sinusoidal acceleration, and earthquake motion. Important contribution was given by 


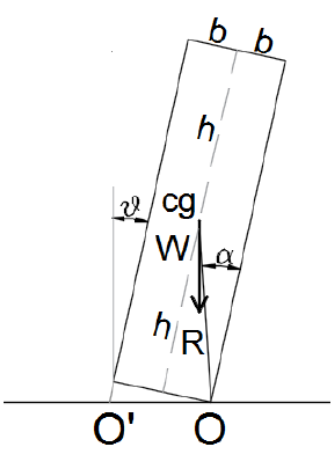

(a)

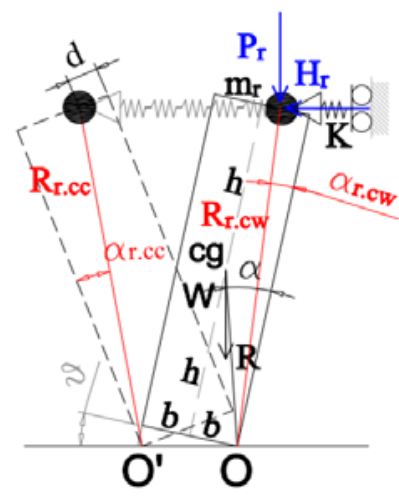

(b)

Figure 30: Rocking rigid block: (a) Housner free block model; (b) restrained rocking block [101]

Aslam et al. [100] who considered the rocking vibrations of the free rigid block under ground motions through a computer program. Considering the rotation $\theta$ (>0 if counter-clockwise) as a Lagrangian coordinate, the equation of motion takes the form: The energy dissipation is accounted for through the "restitution coefficient" $e_{H}=1-\frac{3}{2} \sin ^{2}(\alpha)$, where $\alpha$ is the arctangent of the thickness to height ratio and is valid for slender and rectangular blocks. Giresini et al. [101, 102] modified the equation of motion to consider the influence of possible roof mass, thrust and horizontal restraint through single or bed spring with stiffness $K$, or $K^{\prime}$, respectively, simulating a tie-rod, a flexible diaphragm or transverse walls (Figure 30(b)). Comparison with experimental results demonstrated the accuracy of the method, contrary to the non-linear kinematic approach suggested by the Italian code for OOP mechanism. An improvement of the approach was performed by AlShawa et al. [103] who considered the plasticity of tie rod. The model is used to 
investigate the response to variations of wall geometry and tie characteristics. The most relevant parameter was the steel strength, whereas other subjected to recorded ground motions have been performed in order to com- 


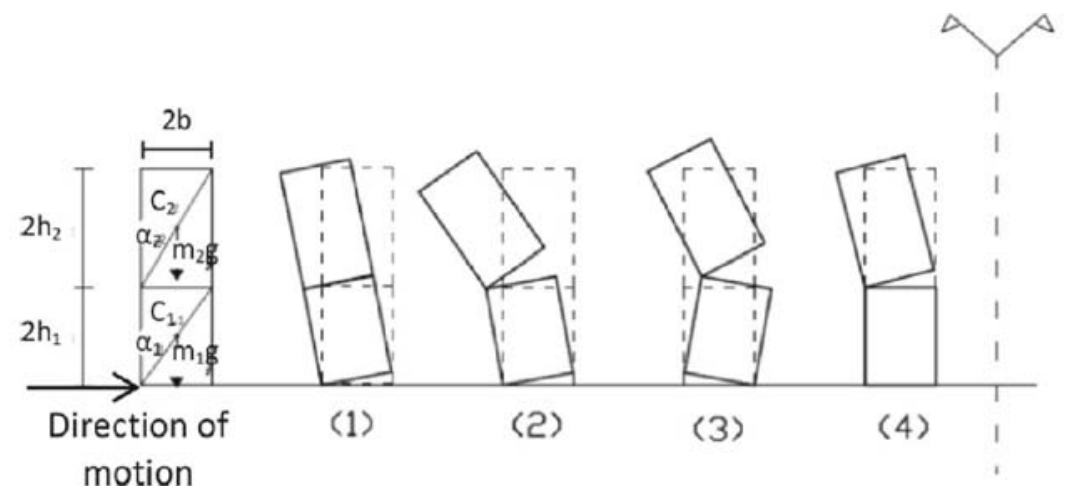

(a)

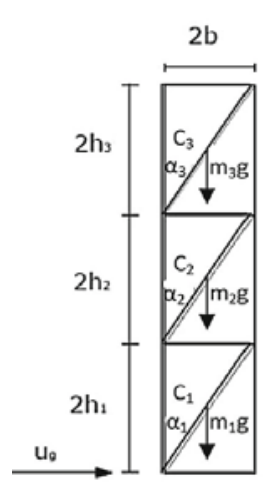

(b)

Figure 31: MDOF configurations of rigid blocks [105] : (a) 2DOF system with $4+4$ possible configurations; (b) 3DOF system

pare the response of the simply supported wall with that of the restrained wall. Four different geometric conditions described by four corresponding sets of equations were studied, and the results compared to a simple 1DOF model, showing that with the increase of the spring stiffness, the response of the $2 \mathrm{DOF}$ model tended to reproduce well the response of the $1 \mathrm{DOF}$ model. On the contrary, with the decrease of the spring stiffness, the top displacement increased and tended to be larger than the mid-height displacement.

A general settlement of the rocking procedure for the vulnerability of the OOP masonry wall, is still far from the professional practise. Currently for masonry structures, standard response spectra are used.

A simple design method for assessing the maximum rocking displacement, 680 using equivalent elastic characteristics and equivalent response spectrum was presented by Priestley et al. [106] and compared to results from simulated seismic excitation of the model using an electro-hydraulic shake-table. Do- 


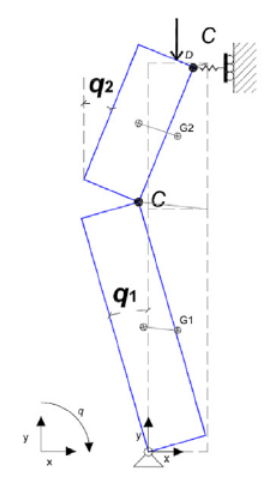

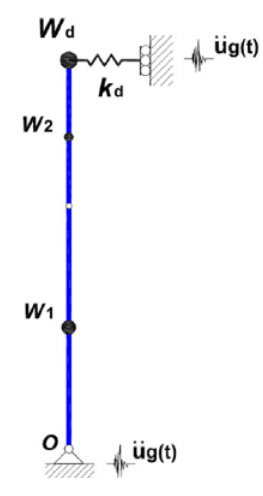

(a)

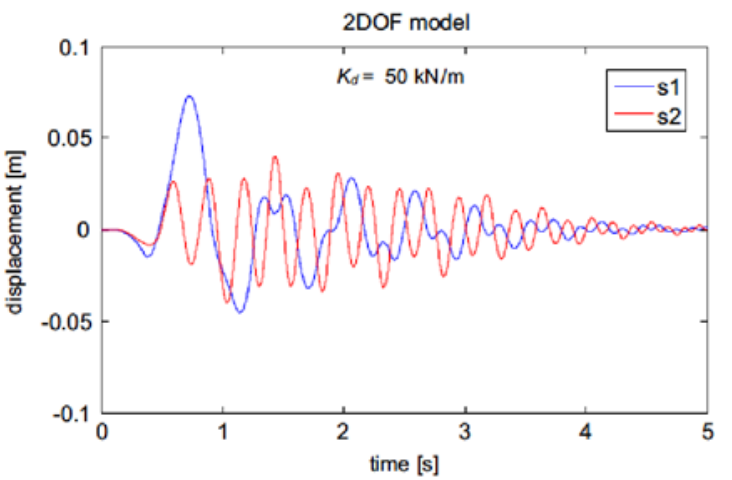

(b)

Figure 32: 2DOF model analysis of the wall in OOP bending [80]: (a) illustration of the model; (b) mid-height (s1) and top (s2) displacements results for $k_{d}=50 \mathrm{kN} / \mathrm{m}$

herty et al. [107] presented a simplified linearized DB procedure based on a trilinear force-displacement relationship of the URM walls (Figure 33(a)). The authors considered both the free and simply supported condition on top (Figure 33(b)) and compared the procedure with NLTH analyses results and with quasi-static analysis showing that less scatter could be reached through DB approach rather then FB procedures. The selection of a proper substitute structure was recommended for each case and the secant stiffness was defined, which was found to correlate well with the predominant natural frequencies observed during experimental testing.

However, distinct differences were noted between rocking spectrum and the classic design response spectrum. Makris and Konstantinidis [108] concluded that the rocking structures cannot be replaced by "equivalent" SDOF oscillators. 


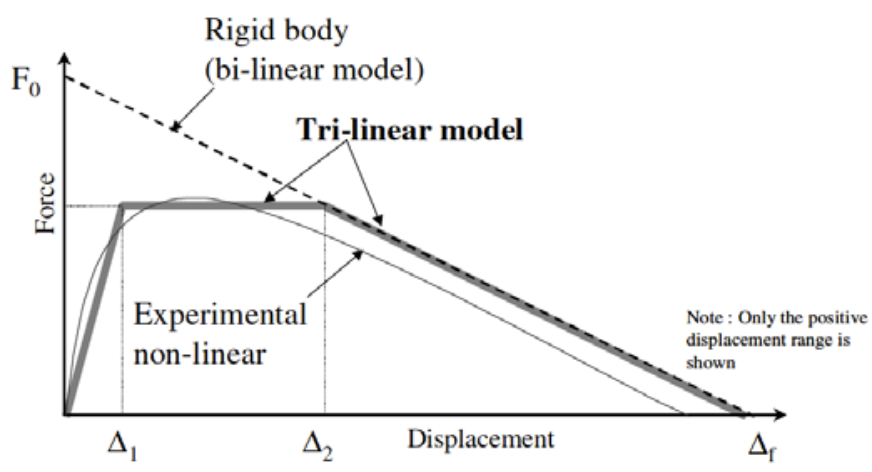

(a)

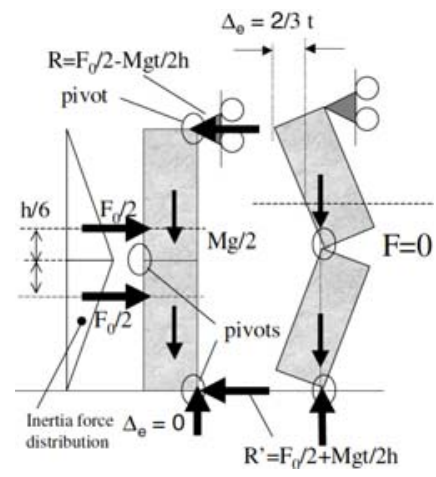

(b)

Figure 33: Linearized DB approached proposed by Doherty et al. [107]: (a) forcedisplacement relationship of URM walls; (b) simply supported masonry wall on top

\subsection{Code Standards}

The seismic capacity of a local mechanism (i.e. OOP wall failure) can be assessed in terms of ultimate displacement through a non-linear kinematic analysis, considering forces given by possible restrains (steel tie rods, beams, etc.) as recommended in the Italian code $[11,12]$, if the monolithic behavior of the block is reasonably assumed. This approach is based on the equilibrium limit analysis and allows for the calculation of the horizontal force which the structure is able to resist, during the evolution of the mechanism. This force-displacement curve can be transformed into the equivalent SDOF system capacity curve (Figure 34(a)) where the Ultimate Limit State (ULS) capacity, $d_{u}^{*}$ is defined in terms of spectral displacement $d^{*}$ and compared to the spectral seismic displacement demand, $S_{D e}\left(T_{s}\right)$ based on the secant period, obtained from the capacity curve:

$$
d_{u}^{*} \geq S_{D e}\left(T_{s}\right)
$$




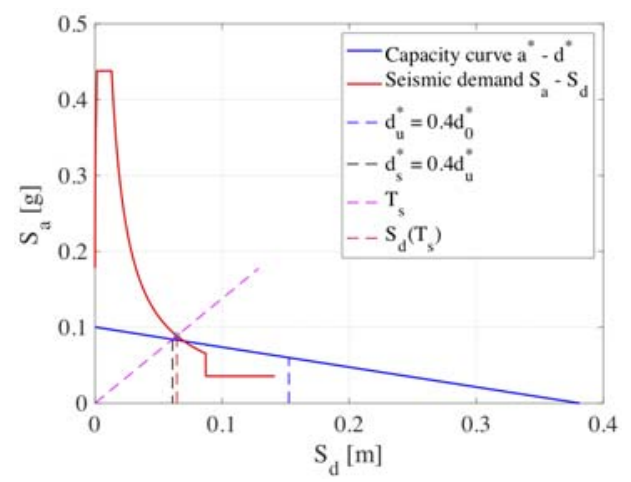

(a)

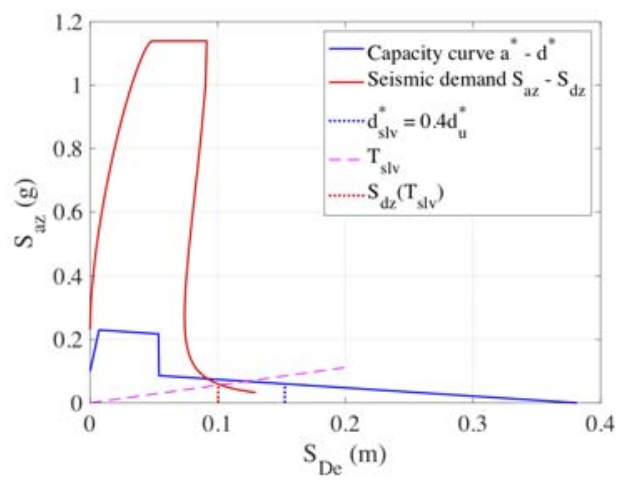

(b)

Figure 34: ULS assessment through the kinematic approach of a masonry wall restrained by a elastic-perfectly plastic spring on top, according to Italian code: (a) NTC2008 [12]; (b) NTC2018 [14]

The Italian code standard also allows for the Damage Limit State (DLS) assessment through the following:

$$
a_{0}^{*} \geq a_{g} S
$$

where $S$ accounts for the type of soil and geographic conditions, while $a_{g}$ is the reference acceleration for the specific geographic coordinates, and $a_{0}^{*}$ is the spectral acceleration that activates the mechanism (Figure 34(a)). Moreover the normative was found to be too conservative for some case studies 715 [109]. On the bases of recent research works $[110,111,112]$ the new Italian standard [14] allows to consider the amplified floor Response Spectrum in case of local mechanisms placed at higher levels of the structure. The seismic demand is defined in terms of overdamped elastic Acceleration Displacement Response spectrum (ADRS), to be compared to the multi-linear 
34(b)). The previous standard [12] considers the amplification assessing simplified expressions, (e.g. C8A.4.12 for ULS),

$$
d_{u}^{*} \geq S_{D e}\left(T_{1}\right) \cdot \psi(Z) \cdot \gamma \frac{\left(\frac{T_{s}}{T_{1}}\right)^{2}}{\sqrt{\left(1-\frac{T_{s}}{T_{1}}\right)^{2}+0.02 \frac{T_{s}}{T_{1}}}},
$$

where, $S_{D e}$ is the elastic displacement response spectrum; $T_{1}$ is the period of the first mode shape of the structure in the interested direction; $\psi(Z)$ is the normalized mode shape assumed as $Z / H$, where $Z$ is the level of the local mechanism, while $H$ is the total height of the structure; $\gamma$ is the coefficient of modal participation and can be assumed as $3 N /(2 N+1)$, where $N$ is the number of floors of the building. The spectral demand obtained through the new standard based on floor spectra may be significantly higher if compared to the previous guideline.

The evaluation of load factors through the kinematic method of limit analysis was recently updated by using rigid-block modelling. An original criterion to account for the frictional resistance in the rocking-sliding failures of URM walls was proposed to assess their in-plane and out-of-plane behaviour [113]. This criterion was validated and applied e.g. to the analysis of the local failure of masonry corners accounting for the role of thrusting timber roofs [114].

If compared to FBA, DBA provide a more rational means of determining seismic design actions for unreinforced masonry walls, avoiding inevitable material mechanical characterization [74]. The limitation of such formulations relies on the quantification of the displacement limit parameters which are calibrated based only on experimental data.

FEMA 547 [115] addresses inadequate or missing wall-to-diaphragm tie 
This paper can be found at https://doi.org/10.1016/j.engstruct.2019.109559

deficiencies suggesting the use of tension and shear ties. Such anchors should transfer OOP inertial loads perpendicular to the face of the masonry back into the diaphragm or shear loads from the diaphragm into the wall where they are resisted by IP action. For tension anchors the use of through bolt anchored to an external steel plate and welded to an internal steel strap, nailed to the joists and timber blockings is suggested in the case of connections with joists parallel to wall. On the other hand, a steel angle connection is suggested for connections where joists are perpendicular to the wall. Adhesive anchors are also recommended for aesthetic reasons giving details of the connection procedure and material to use. A threaded rod is commonly suggested as ATSM A36 all-thread rod, relatively ductile material with high strength capacity. As highlighted from the guideline, holes need to be drilled with a rotary drill with the percussion setting turned off to limit vibration into the wall. The use of a diamond tipped blade is suggested. Eccentricity issues, together with other aspects are discussed and some examples are shown of different types of anchorages.

The ASCE/SEI 41-13 guidelines [116] covers both analysis for the evaluation of existing buildings and design of retrofit measures. Tier 3 systematic procedure is suggested as the most reliable and complete, for which the analysis must include the entire structural system. Four analysis procedures are proposed: linear static procedure (LSP), linear dynamic procedure (LDP), nonlinear static procedure (NSP), or nonlinear dynamic procedure (NDP). Adoption of linear procedures is limited to regular and simple buildings, while nonlinear procedures are encouraged to account for non linearities, usually present in existing constructions. The guidelines set forth analysis 
This paper can be found at https://doi.org/10.1016/j.engstruct.2019.109559

requirement in $§ 7.2 .11 .1$ regarding the OOP wall anchorage to diaphragms. Walls shall be anchored to diaphragms at horizontal distances not exceeding $8 f t(2.44 m)$ and anchorage shall positively transmit the seismic forces generated into the OOP wall to the diaphragm:

$$
F_{p}=0.4 S_{X S} K_{a} K_{h} \chi W_{p}
$$

where $S_{X S}$ is the spectral response acceleration for the selected hazard level and damping, adjusted for the site class; $K_{a}$ is a factor accounting for the flexibility of the floor (not exceeding 2.0), for different Structural Performance Level (SPL); $K_{h}$ is a factor accounting for the variation in force over the height when all diaphragms are rigid; $\chi$ is a factor accounting for different SPL and $W_{p}$ is the weight of the wall tributary to the wall anchor. According to this standard the pullout and shear strength of expansion anchors and adhesive anchors shall be verified by approved test procedures, while for other types of anchors, the lower-bound values for strengths with respect to pullout, shear and combination of both shall be calculated according to approved building code and analysed as force-controlled action. The guideline refers to ACI [117] TMS 402 and FEMA [118] for the design and analysis of anchors. 785 New Zealand guidelines recently published [35] allow for both force-based and displacement-based procedures for the assessment of existing retrofitted URM building. The evaluation is based on the value of the earthquake rating for the building expressed as \%NBS (Percentage of new building standard as assessed by application of these guidelines) obtained by dividing the calcu-

lated ultimate seismic capacity of the component by the ULS seismic demand 
with the following expression:

$$
\% \text { NBS }=\frac{\text { Capacity }}{\text { Demand }} x 100
$$

A building is defined as earthquake risk building (ERB) if $<67 \%$ NBS. These standards define the probable capacity of diaphragm to wall connections as the lowest among 7 different failure modes. These latter failure modes are based on damage observations during 2010/11 Canterbury earthquake sequence and on studies conducted by Campbell et al. [67] (illustrated in Section 4). Probable failure mechanisms are also reported for adhesive anchorages, based on Canterbury earthquake sequence, too. These include, among the others: brick work cracking of the masonry in the proximity of the anchorages loaded in flexural tension; incorrect installation; bed-joint shear failure of the brick around its perimeter. Based on the above considerations, these standards provide tables in lieu of specific testing showing probable shear strength capacity and tension pull-out capacity for different anchorage details. The demand is calculated as the support reactions of the seismic inertial forces generated from the tributary OOP walls. Retrofitted connections are recommended to be stronger than the walls.

\section{Conclusions}

This paper presents a literature review on wall-to-horizontal diaphragm connections in URM buildings, considering the typical connections found in traditional buildings and the main solutions to enhance the seismic behavior of such connections. Both experimental and numerical research studies aimed at mechanically characterizing these connections are reported and discussed. 
This paper can be found at https://doi.org/10.1016/j.engstruct.2019.109559

This study reveals the necessity of accounting for wall-to-floor or wall-to-roof connections in the seismic analysis of existing URM buildings and stresses the

need of simple but clear guidelines for their assessment and recommendations on their numerical modelling.

Considering the peculiarity of the connections, the calibration of numerical models based on experimental data is necessary for a reliable evaluation of the seismic capacity of historical constructions. Despite pull-out monotonic and cyclic tests on detailed connections for the axial and shear capacity are appropriate for this scope, they are costly and complex to set-up. Failure mechanisms and ultimate dynamic capacity can be assessed through shaking table tests on building-scale and wall-scale specimens to understand the influence of the strengthening strategy on the original poor building.

Complex and detailed finite element models reveal to accurately simulate the global behavior of the URM building but they are hardly used from professionals who look for simpler procedure (equivalent frame or macro models). Uncertainties can be found on the definition of the mechanical characteristics of masonry elements and diaphragm are aether not-considered as structural elements or they are modelled as rigidly connected to the perimeter walls. From the literature review, it is clear how the structural nonlinearities are important, especially when dealing with connections. They affect the energy dissipation of the system, and therefore they influence the assessment of both global and local mechanisms. Pushover curves are widely used in the field of masonry constructions to evaluate the ultimate force/displacement capacity taking into account those nonlinearities. Non-linear time-history analysis is also considered to be a valid tool able to better simulate the structural 
This paper can be found at https://doi.org/10.1016/j.engstruct.2019.109559

response under real seismic input. Selection of appropriate input motions, essential for predicting reliable results is, however, a topic requiring clearly further research.

Many code standards still indicate force-based approaches for the assessment of local failure mechanism and only few refer to displacement-based approaches, in many cases more reliable in presence of local URM wall mechanisms. Currently, kinematic analysis proposed in the Italian code is the only one recognized as completely reliable in European Standards, and it can be performed in nonlinear range. Furthermore, the rocking approach considers the evolution of motion during time and dissipation properties at the plastic hinge around which the masonry wall rotates are not neglected. Limitations of such approach rely on the monolithic characteristic of the block, modelled as rigid, not always true for masonry walls or façades. However, improvements of the equation of motion have been done to account for the formation of an intermediate hinge, frequently developed during OOP bending of the walls horizontally restrained on top.

In literature, only few experimental data at connection level are available involving uncertainties on the seismic evaluation of the original or reinforced buildings. Common practise is to perform parametric analyses based on the calibrated model, in order to investigate a large value set of the interesting parameters. This study reveals the necessity of clear and simple readyto-use research-based procedures grounded on experimental and numerical approaches useful for professionals to assess existing wall-to-horizontal diaphragm connections and design strengthening solutions in historical constructions. 


\section{Acknowledgements}

This work was partly financed by FEDER funds through the Operational

865

[4] A. Menon, G. Magenes, Out-of-plane seismic response of unreinforced masonry: definition of seismic input, no. May, IUSS Press, Pavia, 2008.

[5] K. Lang, H. Bachmann, On the seismic vulnerability of existing unre- 
This paper can be found at https://doi.org/10.1016/j.engstruct.2019.109559

inforced masonry buildings, Journal of Earthquake Engineering 7 (3) (2003) 407-426. doi:10.1080/13632460309350456.

[6] J. Bothara, S. Brzev, A Tutorial: Improving the Seismic Performance of Stone Masonry Buildings, first edit Edition, Earthquake Engineering Research Institute, Oakland, California, United States of America, 2011.

[7] M. Tomaževič, Earthquake-Resistant Design of Masonry Buildings, Vol. 1, Imperial College Press, London, UK, 1999. arXiv:arXiv: $1011.1669 \mathrm{v} 3$, doi:10.1142/9781848160835.

[8] N. Ismail, J. M. Ingham, In-plane and out-of-plane testing of unreinforced masonry walls strengthened using polymer textile reinforced mortar, Engineering Structures 118 (2016) 167-177. doi:10.1016/j. engstruct.2016.03.041.

[9] R. Scotta, D. Trutalli, L. Marchi, L. Pozza, Seismic performance of URM buildings with in-plane non-stiffened and stiffened timber floors, Engineering Structures 167 (2018) 683-694. doi:10.1016/j. 900 engstruct.2018.02.060.

[10] EC (Eurocode) 8, Design of structures for earthquake resistance - Part 3: Assessment and retrofitting of buildings (2005).

[11] DMI, Decreto del Ministro delle Infrastrutture 14 gennaio 2008. Approvazione delle nuove norme tecniche per le costruzioni (2008).

[12] CSLLPP, Circolare 02 febbraio 2009 n. 617 Istruzioni per l'applicazione 
delle "Nuove norme tecniche per le costruzioni" di cui al D. M. 14 gennaio 2008 (2009).

[13] Presidenza del Consiglio dei Ministri, Linee Guida per la valutazione e riduzione del rischio sismico del patrimonio culturale con riferimento alle norme tecniche per le costruzioni (2011).

[14] DMI, Decreto 17 gennaio 2018. Aggiornamento delle $\ll$ Norme tecniche per le costruzioni $\gg(2018)$.

[15] T. J. Lin, J. M. LaFave, Experimental structural behavior of walldiaphragm connections for older masonry buildings, Construction and Building Materials 26 (2012) 180-189. doi:10.1016/j.conbuildmat. 2011.06 .008 .

[16] C. Ramsey, H. Sleeper, Architectural graphic standards, New York, United States of America, 1932.

[17] I. T. B. Company, International Library of Technology, Scranton, 1923.

[18] C. B. Cestari, A. D. Lucchio, Interventions on historical building timber floors : Retractable - visible ? Invasive - not visible ? ........ A case study (2001) 837-846.

[19] L. Scali, Il Muratore (2011).

URL http://www.murlocultura.com/old\{_\}site/ MurloCultura\{_\}5\{_\}2011/MurloCultura\{_\}5\{_\}2011\{_\}pag8. html

[20] L. B. Alberti, De re Aedificatoria, Milano, 1452. 
[21] F. Milizia, Principi di Architettura Civile, 1785.

[22] W. Maresta, Construction 102: Mezzanine wooden frame (1) - beams and joists (2018).

[23] V. Scamozzi, L'idea dell'Architettura Universale, Venezia, 1615.

[24] G. Valadier, L'architettura pratica, 1831.

[25] A. R. Emi, Trattato dell'arte del Carpentiere, 1856.

[26] M. Bruneau, State-of-the-art report on seismic performance of unreinforced masonry buildings, Journal of Structural Engineering 120 (1) (1994) 230-251. doi:10.1061/(ASCE) 0733-9445(1994)120:1(230). URL http://ascelibrary.org/doi/abs/10.1061/(ASCE) 0733-9445(1994) 120:1(230)

[27] R. Pareto, G. Sacheri, Enciclopedia delle Arti e delle Industrie, vol. iv Edition, UTET, Torino, 1889.

[28] C. Formenti, La pratica del fabbricare, 1893.

[29] D. Donghi, Manuale dell'Architetto, UTET, Torino, 1923, Ch. Vol. I.

[30] G. Chevalley, Elementi di tecnica dell'architettura, Pasta editore, Torino, 1924.

${ }_{945}^{\text {[31] G. A. Breymann, Trattato delle costruzioni civili, } 1880 .}$

[32] D. F. Peralta, J. M. Bracci, M. B. D. Hueste, Seismic behavior of wood diaphragms in pre-1950s unreinforced masonry buildings, Journal 
This paper can be found at https://doi.org/10.1016/j.engstruct.2019.109559

of Structural Engineering 130 (12) (2004) 2040-2050. doi:10.1061/ (ASCE) 0733-9445(2004) 130:12(2040).

950

[33] V. Cóias, Reabilitação Estrutural de Edifícios Antigos - Alvenaria, Madeira - Técnicas pouco intrusivas, Ed. Argumentum \& Gecorpa (In Portuguese), Lisbon, Portugal, 2007.

[34] J. Appleton, Reabilitação de Edifícios Antigos - Patologias e Tecnologias de Intervenção, Amadora, 2003.

[35] NZSEE, The Seismic Assessment of Existing Buildings Technical Guidelines for Engineering Assessments Part B - Initial Seismic Assessment (October).

[36] M. Tomaževič, M. Lutman, P. Weiss, Seismic upgrading of old brickmasonry urban houses: Tying of walls with steel ties, Earthquake Spectra 12 (3) (1996) 599-622. doi:10.1193/1.1585898.

[37] G. Spina, F. Ramundo, A. Mandara, Masonry strengthening by metal tie-bars, a case study, Structural Analysis of Historical Constructions - Modena, Lourenço \& Roca (eds) (2005) 1207-1214.

[38] C. Calderini, R. Vecchiattini, C. Battini, P. Piccardo, Mechanical and metallographic characterization of iron tie-rods in masonry buildings: An experimental study, in: Van Balen \& Verstrynge (Ed.), Structural Analysis of Historical Constructions: Anamnesis, diagnosis, therapy, controls - Proceedings of the 10th International Conference on Structural Analysis of Historical Constructions, SAHC 2016, Taylor \& Francis Group, London, 2016, pp. 1293-1300. 
This paper can be found at https://doi.org/10.1016/j.engstruct.2019.109559

[39] A. de Falco, L. Giresini, M. Sassu, Temporary Preventive Seismic Reinforcements on Historic Churches: Numerical Modeling of San Frediano in Pisa, Applied Mechanics and Materialsdoi:10.4028/www. scientific.net/AMM. 351-352.1393.

[40] M. Andreini, A. de Falco, L. Giresini, M. Sassu, Collapse of the Historic City Walls of Pistoia (Italy): Causes and Possible Interventions, Applied Mechanics and Materialsdoi:10.4028/www.scientific.net/ AMM . 351-352. 1389.

[41] M. Andreini, A. de Falco, L. Giresini, M. Sasso, Structural Analysis and Consolidation Strategy of the Historic Mediceo Aqueduct in Pisa (Italy)., Applied Mechanics and Materials 352 (Advances in Civil Structures) (2013) 351-352. doi : 10 .4028/www . scientific.net/AMM. $351-352.1354$.

URL http://citeseerx.ist.psu.edu/viewdoc/download.

[42] L. Giresini, M. Sassu, C. Butenweg, V. Alecci, M. D. De Stefano, Vault macro-element with equivalent trusses in global seismic analyses, Earthquake and Structuresdoi:10.12989/eas.2017.12.4.409.

[43] M. Tomaževič, Seismic resistance of masonry buildings in historic urban and rural nuclei: Lessons learned in Slovenia, International Journal of Architectural Heritage 5 (4-5) (2011) 436-465. doi:10.1080/ 15583051003792898 .

[44] M. Tomaževič, I. Klemenc, P. Weiss, Seismic upgrading of old masonry buildings by seismic isolation and CFRP laminates: A shaking-table 
This paper can be found at https://doi.org/10.1016/j.engstruct.2019.109559

study of reduced scale models, Bulletin of Earthquake Engineering 7 (1) (2009) 293-321. doi:10.1007/s10518-008-9086-1.

[45] V. Alecci, M. De Stefano, F. Focacci, R. Luciano, L. Rovero, G. Stipo, Strengthening Masonry Arches with Lime-Based Mortar Composite, Buildingsdoi:10.3390/buildings7020049.

[46] V. Alecci, S. Briccoli Bati, G. Ranocchiai, Numerical homogenization techniques for the evaluation of mechanical behaviour of a composite with SMA inclusions, Journal of Mechanics of Materials and Structures 4 (10) (2009) 1675-1688. doi:10.2140/jomms.2009.4.1675.

[47] V. Alecci, S. Briccoli Bati, G. Ranocchiai, Concrete columns confined with CFRP wraps, Materials and Structures/Materiaux et Constructionsdoi : 10.1617/s11527-013-0068-7.

[48] E. L. Blaikie, D. D. Spurr, Earthquake Vulnerability of Existing Unreinforced Masonry Buildings, Wellington, NZ, 1992.

[49] S. Moreira, Seismic retrofit of masonry-to-timber connections in historical constructions, Ph.d. thesis, University of Minho (2015).

[50] S. Paganoni, D. D'Ayala, D. D'Ayala, Experimental and Computational Validation of Dissipative Prototype for the Seismic Protection of Heritage Buildings, Advanced Materials Research 133-134 (April 2009) (2010) 831-836. doi:10.4028/www. scientific.net/AMR. 133-134. 831.

URL http://www. scientific.net/AMR .133-134.831 
This paper can be found at https://doi.org/10.1016/j.engstruct.2019.109559

[51] NIKER, New Integrated Knowledge-based approaches to the protection of Curtural Heritage from Earthquake-induced Risk: Workpackage 3 and 10 (2010).

[52] M. R. Valluzzi, E. Garbin, M. dalla Benetta, C. Modena, Experimental Characterization of Timber Floors Strengthened by in-Plane Improvement Techniques, Advanced Materials Researchdoi : 10.4028/ WwW.scientific.net/amr.778.682.

[53] I. E. Senaldi, G. Magenes, A. Penna, A. Galasco, M. Rota, The effect of stiffened floor and roof diaphragms on the experimental seismic response of a full-scale unreinforced stone masonry building, Journal of Earthquake Engineering 18 (3) (2014) 407-443. doi:10.1080/ 13632469.2013 .876946 .

[54] International Code Council, International Building Code, Tech. rep., International Code Cuncil, Inc., Country Club Hills, IL (2009).

[55] J. K. Hsiao, J. Tezcan, Seismic retrofitting for chord reinforcement for unreinforced masonry historic buildings with flexible diaphragms, Practice Periodical on Structural Design and Construction 17 (3) (2012) 102-109. doi:10.1061/(ASCE) SC . 1943-5576.0000117.

[56] FEMA, NEHRP Handbook of Techniques for the Seismic Rehabil1035 itation of Existing Buildings (FEMA-172), Building Seismic Safety Council for FEMA, Washington, D.C. (June). doi:10.1061/ 9780784408841. 
This paper can be found at https://doi.org/10.1016/j.engstruct.2019.109559

[57] E. Quagliarini, S. Lenci, F. Monni, S. Vallucci, La conoscenza della fabbrica come strumento di recupero sostenibile. La chiesa di S.M. della

1040

1045

1050

1055 Carità (Ascoli Piceno) (in Italian), Il Progetto Sostenibile 2 (May 2017) (2014) 78-85.

[58] LECA, Laterlite S.P.A. Via Vittorio Veneto 30 - 43046 Rubbiano di Solignano (PR) (2018).

URL www.leca.it

[59] G. Magenes, A. Penna, A. Galasco, a Full-Scale Shaking Table Test on a Two-Storey Stone Masonry Building, in: 14th European Conference on Earthquake Engineering, no. August, Curran, Ohrid, Republic of Macedonia, 2010, p. 384.

[60] A. C. Costley, D. P. Abrams, Dynamic response of unreinforced masonry buildings with flexible diaphragms, Tech. rep., National Center for Earthquake Engineering research, Buffalo, New York (1996).

URL http://hdl .handle.net/10477/615

[61] J. Bothara, R. P. Dhakal, J. B. Mander, Seismic performance of an unreinforced masonry building: An experimental investigation, Earthquake Engineering and Structural Dynamics (39) (2010) 45-68. arXiv:1403.5481, doi:10.1002/eqe.

URL http: //arxiv.org/abs/1403.5481

[62] G. Magenes, A. Penna, I. E. Senaldi, M. Rota, A. Galasco, Shaking table test of a strengthened full-scale stone masonry building with flex- 
This paper can be found at https://doi.org/10.1016/j.engstruct.2019.109559

ible diaphragms, International Journal of Architectural Heritage 8 (3) (2014) 349-375. doi:10.1080/15583058.2013.826299.

[63] E. Vintzileou, C. Mouzakis, C. E. Adami, L. Karapitta, Seismic behavior of three-leaf stone masonry buildings before and after interventions: Shaking table tests on a two-storey masonry model, Bulletin of Earthquake Engineering 13 (10) (2015) 3107-3133. doi: $10.1007 / \mathrm{s} 10518-015-9746-\mathrm{x}$.

[64] A. Dazio, The effect of the boundary conditions on the out-of-plane behaviour of unreinforced masonry walls, in: Proceedings of the 14th World Conference on Earthquake Engineering, Beijing, China, 2008.

[65] C. C. Simsir, M. A. Aschheim, D. P. Abrams, Out-of-plane dynamic response of unreinforced bearing walls attached to flexible diaphragms, in: Proceedings of 13th World Conference on Earthquake Engineering, no. 2045,2004 , p. 15 .

[66] D. H. Jacks, G. J. Beattie, Dynamic Testing of Seismic Anchors in Unreinforced Brick Masonry Walls (1990).

[67] J. Campbell, D. Dizhur, M. Hodgson, G. Fergusson, J. M. Ingham, Test results for extracted wall-to-diaphragm anchors from Christchurch unreinforced masonry buildings, SESOC Journal 25 (1) (2012) 57-67.

[68] A. R. A. Karim, P. Quenneville, N. M. Sa'don, J. M. Ingham, Assessment guidelines of wall-diaphragm connections for masonry buildings, in: 7th International Structural Engineering and 
This paper can be found at https://doi.org/10.1016/j.engstruct.2019.109559

Construction Conference, 2013, pp. 1019-1024. doi:10.3850/ 978-981-07-5354-2St-136-427.

[69] N. Ismail, Performance of Wall to Diaphragm Anchors for Use in Seismic Upgrade of Heritage Masonry Buildings, International Journal of Architectural Heritage 10 (7) (2016) 829-840. doi:10.1080/ 15583058.2016 .1144115 .

URL http://dx.doi.org/10.1080/15583058.2016.1144115https:

//doi.org/10.1080/15583058.2016.1144115

[72] D. Dizhur, M. Giaretton, J. M. Ingham, URM wall-to-diaphragm and timber joist connection testing, in: 10th International Masonry Conference - IMC, 2018.

[73] L. Sorrentino, D. D’Ayala, G. de Felice, M. C. Griffith, S. Lagomarsino, 1100

[70] D. Dizhur, A. Schultz, J. M. Ingham, Pull-out behavior of adhesive connections in unreinforced masonry walls, Earthquake Spectra 32 (4) (2016) 2357-2375. doi:10.1193/011115EQS006M.

[71] W. Fuchs, R. Eligehausen, J. E. Breen, Concrete capacity design (CCD) approach for fastening to concrete, ACI Structural Journaldoi : $10.14359 / 1533$.

G. Magenes, Review of Out-of-Plane Seismic Assessment Techniques Applied To Existing Masonry Buildings, International Journal of Architectural Heritage 11 (1) (2017) 2-21. doi:10.1080/15583058.2016. 1237586. 
This paper can be found at https://doi.org/10.1016/j.engstruct.2019.109559

URL http://dx.doi.org/10.1080/15583058.2016.1237586https:

1105

1110

1115 //doi.org/10.1080/15583058.2016.1237586

[74] T. M. Ferreira, A. A. Costa, A. Costa, Analysis of the Out-Of-Plane Seismic Behavior of Unreinforced Masonry: A Literature Review, International Journal of Architectural Heritage 9 (8) (2015) 949-972. doi:10.1080/15583058.2014.885996.

URL http://dx.doi.org/10.1080/15583058.2014.885996https: //doi.org/10.1080/15583058.2014.885996

[75] C. Casapulla, L. Giresini, P. B. Lourenço, Rocking and Kinematic Approaches for Rigid Block Analysis of Masonry Walls: State of the Art and Recent Developments, Buildings 7 (3) (2017) 69. doi: 10.3390/buildings7030069.

URL http://www.mdpi.com/2075-5309/7/3/69

[76] L. Giresini, Energy-based method for identifying vulnerable macroelements in historic masonry churches, Bulletin of Earthquake Engineeringdoi : 10.1007/s10518-015-9854-7.

[77] G. de Felice, S. De Santis, P. B. Lourenço, N. Mendes, Methods and Challenges for the Seismic Assessment of Historic Masonry Structures, International Journal of Architectural Heritage 11 (1) (2017) 143-160. doi: $10.1080 / 15583058.2016 .1238976$.

URL http://dx.doi.org/10.1080/15583058.2016.1238976https: //doi.org/10.1080/15583058.2016.1238976

[78] A. Penna, Seismic assessment of existing and strengthened stone- 
This paper can be found at https://doi.org/10.1016/j.engstruct.2019.109559

masonry buildings: Critical issues and possible strategies, Bulletin of Earthquake Engineering 13 (4) (2015) 1051-1071. doi:10.1007/ s10518-014-9659-0.

1130

1135

1140

[83] M. Priestly, Seismic behaviour of unreinforced masonry walls, Bulletin of the New Zealand National Society for Earthquake Engineering 18 (2) (1985) 191-205. 
This paper can be found at https://doi.org/10.1016/j.engstruct.2019.109559

[84] A. Tena-Colunga, D. Abrams, Seismic behavior of structures with

1150 flexible diaphragms, Journal of Structural Engineering 122 (4) (1996) 439-445. doi:10.1061/(ASCE) 0733-9445(1996) 122:4(439).

URL http://ascelibrary.org/doi/abs/10.1061/(ASCE) 0733-9445(1996) $122: 4(439)$

[85] A. A. Costa, Seismic Assessment of the Out of Plane Performance of Traditional Stone Masonry Walls (March 2012) (2012) 233.

[86] C. S. Oliveira, J. V. Lemos, G. E. Sincraian, Modelling large displacements of structures damaged by earthquake motions, European Earthquake Engineering 3 (2002) 56-71.

[87] J. Ortega, G. Vasconcelos, H. Rodrigues, M. Correia, Assessment of the influence of horizontal diaphragms on the seismic performance of vernacular buildings (2018). doi:10.1007/s10518-018-0318-8.

[88] A. Formisano, G. Ciccone, A. Mele, Large scale seismic vulnerability and risk evaluation of a masonry churches sample in the historical centre of Naples, AIP Conference Proceedings 1906. doi: $10.1063 / 1.5012360$.

[89] F. Clementi, V. Gazzani, M. Poiani, S. Lenci, Assessment of seismic behaviour of heritage masonry buildings using numerical modelling, Journal of Building Engineering 8 (2016) 29-47. doi : 10 .1016/j · jobe. 2016.09 .005 .

URL http://dx.doi.org/10.1016/j.jobe.2016.09.005 
This paper can be found at https://doi.org/10.1016/j.engstruct.2019.109559

[90] F. Clementi, V. Gazzani, M. Poiani, P. Antonio Mezzapelle, S. Lenci, Seismic Assessment of a Monumental Building through Nonlinear Analyses of a 3D Solid Model, Journal of Earthquake Engineering 22 (sup1) (2018) 35-61. doi:10.1080/13632469.2017.1297268. URL https://doi.org/10.1080/13632469.2017.1297268http: //dx.doi.org/10.1080/13632469.2017.1297268

[91] A. Formisano, G. Vaiano, F. Fabbrocino, G. Milani, Seismic vulnerability of Italian masonry churches: The case of the Nativity of Blessed Virgin Mary in Stellata of Bondeno, Journal of Building Engineering 20 (2018) 179-200. doi:10.1016/j.jobe.2018.07.017.

URL https://doi.org/10.1016/j.jobe.2018.07.017

[92] S. Lagomarsino, A. Penna, A. Galasco, S. Cattari, TREMURI program: An equivalent frame model for the nonlinear seismic analysis of masonry buildings, Engineering Structuresdoi:10.1016/j.engstruct. 2013.08 .002$.

[93] E. Quagliarini, G. Maracchini, F. Clementi, Uses and limits of the Equivalent Frame Model on existing unreinforced masonry buildings for assessing their seismic risk: A review, Journal of Building Engineering 10 (2017) 166-182. doi:10.1016/j.jobe.2017.03.004.

1190

[94] B. Pantò, F. Cannizzaro, S. Caddemi, I. Caliò, 3D macro-element modelling approach for seismic assessment of historical masonry churches, Advances in Engineering Software 97 (2016) 40-59. doi:10.1016/j. advengsoft.2016.02.009. 
This paper can be found at https://doi.org/10.1016/j.engstruct.2019.109559

[95] B. W. B. Cross, N. P. Jones, ASCE, Seismic Performance of Joist-

1195 Pocket Connections. I: Modeling, Journal of Structural Engineering 119 (10) (1994) 2986-3007.

[96] A. Giuffrè, Seismic safety and strengthening of historical buildings and urban fabrics, in: Earthquake Engineering, Tenth World Conference, Balkema, Rotterdam., 1994, pp. 6583-96.

[97] D. D’Ayala, E. Speranza, Definition of Collapse Mechanisms and Seismic Vulnerability of Historic Masonry Buildings, Earthquake Spectra 19 (3) (2003) 479-509. doi:10.1193/1.1599896.

[98] S. Lawrence, R. Marshall, Virtual Work Design Method for Masonry Panels under Lateral Load, 12th International Brick/Block Masonry Conference (2000) 1063-1073.

[99] G. W. Housner, The behavior of inverted pendulum structures during earthquakes, Bulletin of the Seismological Society of America 53 (2) (1963) 403-417. doi:10.1017/CB09781107415324.004.

[100] M. Aslam, W. G. Godden, D. T. Scalise, Earthquake Rocking Response of Rigid Bodies, Journal of the Structural Division 106 (2) (1980) 377392.

[101] L. Giresini, M. Fragiacomo, M. Sassu, Rocking analysis of masonry walls interacting with roofs, Engineering Structures 116 (2016) 107120.

[102] L. Giresini, C. Casapulla, R. Denysiuk, J. Matos, M. Sassu, Fragility curves for free and restrained rocking masonry façades in one-sided 
This paper can be found at https://doi.org/10.1016/j.engstruct.2019.109559

motion, Engineering Structures 164 (February) (2018) 195-213. doi: $10.1016 / j$. engstruct .2018 .03 .003$.

URL https://doi.org/10.1016/j.engstruct.2018.03.003

[107] K. T. Doherty, M. C. Griffith, N. Lam, J. Wilson, Displacement-based seismic analysis for out-of-plane bending of unreinforced masonry walls, Earthquake Engineering and Structural Dynamics 31 (4) (2002) 833850. doi:10.1002/eqe.126. 
This paper can be found at https://doi.org/10.1016/j.engstruct.2019.109559

[110] S. Lagomarsino, Seismic assessment of rocking masonry structures, Bulletin of Earthquake Engineering 13 (1) (2014) 97-128. doi:10. 1007/s10518-014-9609-x.

[111] S. Degli Abbati, S. Lagomarsino, Out-of-plane static and dynamic re-

[108] N. Makris, D. Konstantinidis, The rocking spectrum and the limitations of practical design methodologies, Earthquake Engineering and Structural Dynamics 32 (2) (2003) 265-289. doi:10.1002/eqe.223.

[109] L. Giresini, Rocking and kinematic analysis of two masonry church façades, Structural Analysis of Historical Constructions - Anamnesis, diagnosis, therapy, controls (October) (2016) 1190-1196.

sponse of masonry panels, Engineering Structures 150 (2017) 803-820. doi:10.1016/j.engstruct.2017.07.070.

URL http://dx.doi.org/10.1016/j.engstruct.2017.07.070

[112] S. Degli Abbati, S. Cattari, S. Lagomarsino, Theoretically-based and practice-oriented formulations for the floor spectra evaluation, Earthquakes and Structures 15 (5) (2018) 000-000.

[113] C. Casapulla, L. U. Argiento, In-plane frictional resistances in dry block masonry walls and rocking-sliding failure modes revisited and experimentally validated, Composites Part B: Engineering 132 (2018) 197213. doi:10.1016/j.compositesb.2017.09.013.

[114] C. Casapulla, A. Maione, L. U. Argiento, E. Speranza, Corner failure in masonry buildings: An updated macro-modeling approach with frictional resistances, European Journal of Mechanics, A/Solids 
This paper can be found at https://doi.org/10.1016/j.engstruct.2019.109559

70 (March) (2018) 213-225. doi:10.1016/j.euromechsol.2018.03. 003. URL https://doi.org/10.1016/j.euromechsol.2018.03.003

[115] Federal Emergency Management Agency, FEMA 547: Techniques for the Seismic Rehabilitation of Existing Buildings (2006). doi : 10.1061/ 9780784408841.

[116] American Society of Civil Engineers (ASCE), ASCE/SEI 41-13 : Seismic evaluation and retrofit of existing buildings, 2013.

[117] ACI, Building code requirements and specification for masonry structures, Tech. rep. (2008).

[118] FEMA, NEHRP Recommended Seismic Provisions (2009) 383doi : 10. 1017/CB09781107415324.004T4-DesignExamplesM4-Citavi. 